\title{
Healing and 'Civilizing': Community and Safety in Psychiatric Care
}

In early 1927, Schweitzer informed his supporters in Europe about Njambi, a patient who had been brought to the Albert Schweitzer Hospital in chains a few months earlier:

In mental derangement, he had killed a woman. In the cell he slowly calmed down. Now he has reached the point where he is allowed to move around freely under surveillance and to occupy himself. He sharpens axes and goes into the forest with Miss Russell and helps cutting down trees. $^{1}$

Since this is not a horror thriller, I can assure you that the story continued well for Miss Russell. ${ }^{2}$ Njambi's subsequent story would be marked by numerous ups and downs. While his cell would frequently become the source of security concerns - a scene of recurring violence and, in response, involuntary drugging - he and his fellow psychiatric patients were to be 'civilized' through occupational therapy.

An analysis of psychiatric care and the reasoning behind it allows reconstructing how the latter influenced the former. Like many of their colleagues all over the world, Schweitzer and some of his psychiatric personnel believed that the modernity imposed by colonialism represented a threat to the mental health of colonized persons, but at the same time suggested that the existing beliefs of their patients were to blame for their mental illnesses. While the number of psychiatric patients at the hospital was relatively low, it rose from six in the late 1920 s to twenty-five in the 1960s, the many case studies in the sources allow for an analysis of how patients and their communities understood their own disorders.

1 Schweitzer, Mitteilungen aus Lambarene. Drittes Heft, 1925-1927, 53.

2 Lilian Russell returned repeatedly to Lambaréné to work in the plantations, a task that would later be performed by psychiatric patients. She also supported Schweitzer from abroad, for example by translating parts of his work. Russell was the first person to bring a video camera to the hospital. The short film 'Aus dem Urwaldspital von Dr. Albert Schweitzer in Lambarene (1935)' was made from her material. 


\section{Psychiatric Services and Ideology in Colonial Africa and at the Hospital}

In colonial Africa, few hospitals offered beds to psychiatric patients, and the number of asylums remained constantly low. ${ }^{3}$ This indicates that the Foucauldian confinement of deviant individuals was not common during this period. ${ }^{4}$ Before asylums began to be established on a more regular basis in African colonies in the opening decades of the twentieth century, it was not unusual for psychiatric patients, African and European, to be sent to facilities in the metropole. ${ }^{5}$ Early African asylums did not differ significantly from those in Europe, with mental institutions on both continents custodial in nature. ${ }^{6}$ Numerous observers compared the conditions in African asylums to those of prisons, often unfavorably. ${ }^{7}$ A more therapeutic and less restrictive approach was only adopted in African institutions after 1950.

Until at least 1950, the so-called ethnopsychiatrists, colonial doctors and medical researchers working at the interface of psychiatry and ethnography, were important drivers of debates on African mental health. Their underlying assumption was that the minds of Africans functioned differently to those of Europeans. They began by explaining 'African inferiority [...] in terms of physical endowment and brain structure', then with reference to 'cultural patterns and child-rearing conventions. ${ }^{8}$ While these findings were challenged by a number of peers, they were more often reinforced by contemporary scientific methodologies. ${ }^{9}$ Since the 'Other' was located within the colonial subject in this construction, mentally ill Africans, unlike their European counterparts, became 'insufficiently "Other"', as Megan Vaughan terms it. They were individuals 'who spoke of being rich, of hearing voices through radio sets, of being powerful, who imitated the white man in dress and behaviour.'10 Such discussions on

3 One of these was Mengo Hospital in Uganda. See: Pringle, 'Neurasthenia at Mengo Hospital, Uganda'.

$4 \quad$ Keller, 'Madness and Colonization', 313; Vaughan, 'Psychiatry and Empire, Introduction', 2.

5 Ngalamulume, 'The Regulation of Madness in Sénégal, 1890-1914'; Scarfone, 'Italian Colonial Psychiatry', 397.

$6 \quad$ Porter, 'Madness and Its Institutions', 278.

7 In East Africa, asylums emerged out of the prison system, with patients usually forcibly committed. See: Mahone, 'East African Psychiatry and the Practical Problems of Empire', 43. On the comparison with prisons, see:Vaughan, 'Psychiatry and Empire, Introduction', 2.

8 McCulloch, Colonial Psychiatry and the African Mind, 141.

9 Ibid., 75; Vaughan, Curing Their Ills, 109-15.

10 Vaughan, Curing Their Ills, 101. Lynette Jackson underlines how, given this discursive context, mentally ill African women, as the 'others' other', posed a particular challenge for colonial officials. See: Jackson, Surfacing Up, 102. 
racial difference were at the core of a wider debate, 'namely whether the emphasis of the colonial regime should be on providing stability to the subject population or on undertaking grand projects of social transformation." Ethnopsychiatrists, and a broad variety of colonial interest groups who shared their views, favored the latter option because they assumed that Europeans, their minds, and their 'civilization' were superior to the societies of colonized peoples. This belief persisted well into the 1950 s before coming under increasing challenge from anti-colonial movements across the world. ${ }^{12}$

In his early years in Gabon, Schweitzer subscribed to Darwinian ideas in this respect. He believed that different societies possessed essentially the same culture, but were at different stages in their evolutionary journey towards 'civilization'. Matthieu Arnold, who has analyzed the sermons that Schweitzer gave in Lambaréné until 1934, offers an intriguing analogy to describe this asymmetric relationship between societies: 'the one between the doctor, who rescues, and the patient, who is saved.13 The well-known analogy that Schweitzer proposed himself in 1921 is that of an older and a younger brother. ${ }^{14}$

In later years, Schweitzer stopped referring to evolutionary stages, choosing instead to emphasize inherent differences between cultures. In 1953, he wrote a letter to the French writer Marcel Thiébaud, asking him to treat it 'absolutely confidential'. Nowhere else did Schweitzer express his thoughts on the political and social state of France's African colonies in such an outspoken manner:

The big question: Will the natives be capable of administering themselves? The answer of those who know their mentality: they are not capable and will never be. [...] Living with the least effort is his ideal. [...] This is his mentality. We'll never change it. [...] They live in a world that is a product of civilization. They live in this world, they inhabit it, but they do not belong to it spiritually. ${ }^{15}$

Besides the negative and static image of Africans that Schweitzer conveys here, it is noteworthy that he considered spirituality to be an important feature of his conception of 'civilization'. According to his theory, 'civilization', which was by definition Western, shaped and encompassed people's life all the way to Lambaréné. Africans, who defied the principles that underlay Schweitzer's

\footnotetext{
11 Heaton, Black Skin, White Coats, 32.

12 McCulloch, Colonial Psychiatry and the African Mind, 138.

13 Arnold, 'Vous les noirs, nous les blancs', 440.

14 Schweitzer, Zwischen Wasser und Urwald, 124.

15 Schweitzer to Thiébaud, 24 July 1953, AMs.
} 
ideal, were not really part of it. This understanding influenced the way in which patients were treated at the hospital, as is especially obvious in the case of the mentally ill.

However, as discussed in the Introduction, Schweitzer also viewed Western 'civilization' in a negative light and wanted to protect Africans from its adverse influences. As argued in Chapters 2 and 3, he refrained from intruding into certain spheres of African life. Such an approach to healthcare in developing countries had become more widely accepted by the 1960 s, by which time the notion of a European 'civilizing mission' no longer went unquestioned. In the words of Michael A. Woodbury, who was part of a team of psychiatrists who visited Lambaréné for two weeks in late 1963, Schweitzer

shows no great desire to impose any part of a civilization that may have produced the most beautiful bathrooms in the world but has also developed the most efficient man-killing machines ever devised. And as psychiatrists we know, moreover, that cleanliness, anal training, and destructiveness may be closely related. ${ }^{16}$

The omnipresence of African labor at the hospital suggests that Schweitzer believed that the institution should serve as a vehicle to diffuse a particular version of the 'civilizing mission' rooted in manual labor and shaped by Christian ethics and spirituality. For Schweitzer, infrastructure development and schooling were not central aspects of this quest, as he stated in 1924. According to him, the key question was 'how will the blacks become hardworking people?' He offered a simple answer, namely that 'they become hardworking through religious and moral instruction and through workmanship. ${ }^{17}$ Thirty years later, he expressed his views on the topic in very similar words. 'One of the great tasks facing those who work with primitives and semi-primitives is to educate them in the right estimation of manual labor', he wrote. ${ }^{18}$

The central position assumed by labor in Schweitzer's conception of the 'civilizing mission' is especially evident in the case of psychiatric care. Manual

16 Woodbury et al., 'Psychiatric Care at the Albert Schweitzer Hospital', 149. Woodbury was the director of research and psychotherapy at the Prangins clinic in the Swiss canton of Vaud. He was accompanied to Lambaréné by Elizabeth S. Palacios, a psychiatrist based at Chestnut Lodge, a psychiatric institution in Maryland, and William Thomas, an auxiliary at Crownsville State Hospital, Maryland. They were sponsored by the Visiting International Psychiatric Teams, Inc. No further information on these individuals or this corporation could be found.

17 Schweitzer, 'Mitteilungen aus Lambarene. Zweites Heft, 1924-1925', 130.

18 Schweitzer, 'Briefe aus dem Lambarenespital Oktober 1954', 16. 
labor had long been an everyday feature of life at institutions for the mentally ill in colonial and metropolitan settings alike. In the first half of the nineteenth century, inmates of European asylums were typically put to work, 'partly for reasons of economy, partly implementing an ideology of cure through labour.' ${ }^{19}$ These two motives also drove practices in colonial asylums, except in the case of European patients, who were exempted from duties of manual labor. ${ }^{20}$ Since most studies of psychiatric institutions in Africa do not focus on aspects of patients' day-to-day life, the role of work in African asylums remains unclear. Ingutsheni Mental Hospital in colonial Zimbabwe is one exception; there, 'work was such a central feature of the psychiatric hospital routine that many patients, when asked why they were at the hospital, replied that they had been sent there to work. ${ }^{21}$ In the mid-1920s, African patients at the institution were ordered to grow cotton. ${ }^{22}$ When the superintendent attempted to compel European inmates to likewise participate in such work, he risked upsetting the colonial social order so deeply that he was dismissed from his post. ${ }^{23}$

For the most part, work in colonial asylums was intended as a means of keeping patients busy rather than healing them. Efforts to cure patients became more widespread only in the late 1930s, when new therapeutic technologies, such as lobotomies and electroconvulsive therapy, became available. ${ }^{24}$ In the mid-1950s, psychoactive drugs, known today as antipsychotics or neuroleptics, renewed hopes of developing cures for mental illness. ${ }^{25} \mathrm{~A}$ variety of drugs had hitherto been used to treat mental afflictions, ${ }^{26}$ but the extent of drug use in psychiatric cases now rose to a new level. Doctors appreciated the ability of

19 Porter, 'Madness and Its Institutions', 296. In Germany, encouraging 'usefulness' among psychiatric patients was considered important in the early twentieth century, but occupational therapy never enjoyed a prominent status, unlike in Switzerland, for example, where it generated more interest. See: Schott and Tölle, Geschichte der Psychiatrie, 443. In South-East Asian asylums, whereas local patients participated in harvesting crops, construction work, painting, and laundry tasks, European inmates enjoyed 'outdoor leisure activities'. Edington, Beyond the Asylum, 153.

21 Jackson, Surfacing Up, 161.

22 Ibid., 50-51.

23 Ibid., $150-55$.

24 Psychiatrists in Algeria were at the forefront of testing and administering these therapies, achieving curative success rates far exceeding those in metropolitan France. See: Keller, 'Taking Science to the Colonies', 27-28. In relation to Nigeria in the 1930s, Sadowsky notes that 'although officials usually saw little ambiguity in the identification of African lunatics, the cure of these persons was seen beyond colonial competence'. Sadowsky, Imperial Bedlam, 37 .

25 Keller, 'Taking Science to the Colonies', 34-35; Heaton, Black Skin, White Coats, 161.

26 Pringle, 'Neurasthenia at Mengo Hospital, Uganda', 255. The Albert Schweitzer Hospital is a further case in point, as we will see. 
antipsychotics to suppress the major symptoms of a range of mental illnesses. Their apparent universality 'also helped to foster the reemergence of biological notions of the nature of the human mind: ${ }^{27}$ These drugs were popular among patients, or more precisely their therapy management group, too. Mentally ill individuals in colonial Zimbabwe, for example, were taken to psychiatric clinics to be pacified, but continued to consult local healers when seeking a diagnosis or a cure. ${ }^{28}$

Antipsychotics were considered crucial for the success of the new therapeutic approaches that emerged in the late 1950s, such as that exemplified in the Aro Village Scheme established and operated by a group of Nigerian psychiatrists. In line with contemporary global trends, participating doctors administered antipsychotics to stabilize patients in order to perform 'psychoanalysis, community therapy, or other forms of social psychiatry'. ${ }^{29}$ They also cooperated with local traditional healers during therapy. ${ }^{30}$ In Dakar, the Fann neuropsychological clinic introduced an open-door policy that permitted relatives to stay with patients. It also regularly organized a 'Penc, a meeting of the hospital ward, modeled on a village palaver'. ${ }^{31}$

At the Albert Schweitzer Hospital, the wider community was granted no role in therapeutic practices. Instead, psychiatric patients were sought to be included into a community within the hospital. Occupational and pharmaceutical therapies were applied for this purpose from very early on. The ways in which labor, drugs, and community were intertwined in this process is a central focus of this chapter. Unlike other colonial doctors and consistent with the therapeutic optimism he displayed in the fight against leprosy and other infectious diseases, Schweitzer had already envisioned being able to cure mentally ill patients in the $1920{ }^{32}$ In 1931, he reported to the congregation at the Guildhouse in London, whose members were particularly supportive of his psychiatric endeavors, that 'several of our insane people were cured'. 33

27 Heaton, Black Skin, White Coats, 26.

28 Jackson, Surfacing Up, 11.

29 Heaton, Black Skin, White Coats, 176. However, frustration at the use of these drugs soon grew in Nigeria. Psychiatrists felt that they were not able to execute proper psychotherapeutic work because antipsychotics were being used simply to reduce the number of staff working at psychiatric institutions.

30 This pushed Nigerian-born, Western-trained psychiatrists into a specialist role as gatekeepers who claimed to be uniquely capable of understanding issues arising in the fusion of traditional therapies with biomedical practices. See Chapter 5 of: Heaton, Black Skin, White Coats.

31 Collignon, 'Some Aspects of Mental Illness in French-Speaking West Africa', 172.

32 Schweitzer, 'Mitteilungen Aus Lambarene 1924-25', 157.

33 Schweitzer to Schweitzer Comittee, 2 July 1931, AWHS. 
In the early 1960s, by which time it was more widely believed that the mentally ill could be cured of their afflictions, a number of visiting psychiatrists expressed their esteem of the therapeutic practices at the Albert Schweitzer Hospital. George R. Andrews, who visited the hospital from Wisconsin for one week in 1961, praised the institution's combined approach of pharmaceutical and occupational therapy as effective in 'helping the patient make a transition as quickly as possible back to the community' ${ }^{34}$ Three years later, Woodbury declared that Schweitzer's 'psychiatric service is a more therapeutic ward than the majority I have visited in the United States or in Europe.' ${ }^{35}$ Dr. Louise JilekAall, who would later become a professor of psychiatry at the University of British Columbia, claimed that 'many a psychiatric patient had recovered enough under the care of the hospital staff to return to his village', although 'some would come back looking for help again when they felt a relapse threatened their lives or that of other villagers'. ${ }^{36}$ The confinement and isolation of psychiatric patients was thus presented as being in the best interests of their communities, while at the same time offering the best hope for a cure.

Despite such claims that emphasize the therapeutic nature of the hospital's approach, in practice staff was more concerned about enforcing confinement. Doctors at the hospital did regularly acknowledge failures to heal the mentally ill. Many admitted the limits of their understanding of local lifeworlds. Such instances furnish the historian with opportunities to study doctors' beliefs about what caused mental illness among Africans.

Schweitzer often attributed unsuccessful attempts to cure patients, including mentally ill, to his belief that they had been poisoned, an opinion that he and others maintained throughout the study period. ${ }^{37}$ At the same time, he also speculated that poisoning was an overly invoked explanation for mysterious deaths or symptoms. ${ }^{38}$ In one way or another, however, poison features in most of the examples presented in this chapter. Besides explaining diagnostic and therapeutic limits, doctors attributed poisoning to the worldview of their patients, which many perceived as fundamentally different from their own, backward and irrational. According to the doctors' argumentation, only such contexts would enable poisoning and only individuals adhering to such beliefs would suffer from fear of being poisoned. In 1936, for example, Dr. Heinz

Andrews, 'Psychiatric Facilities at the Albert Schweitzer Hospital', 526. No further information on Andrews could be found.

36 Jilek-Aall, Working with Dr. Schweitzer, 163.

37 For a summary of examples thereof, see: Ohls, Improvisationen der Ehrfurcht vor allem Lebendigen, $184-88$.

38 Schweitzer, Zwischen Wasser und Urwald, 47. 
Barasch reported that 'we house a new insane man; a schizophrenia with persecution ideas. (Supposedly, his family wants to poison him)'.39 Here, Barasch considered the fear of poisoning to be a form of persecution mania. In this reasoning, the patient's adherence to his 'irrational' worldview made him sick, with his beliefs in the possibility of being poisoned to blame for his pathological fear.

Schweitzer likewise believed that their 'superstition' was not beneficial for his patients' mental health. He maintained that he and his staff were unable to fully understand those 'superstitions'. In 1939, he reflected in great detail on his inability to relate to his patients or their lifeworlds:

The natives who come to us in our hospital and let us treat them often have thoughts of which we do not know anything. As a result of a taboo, a curse or a spell, their soul is in an emotional distress that remains hidden from us. [...] We always regret that our patients so rarely bring it about themselves to let us take a look at the emotional misery in which they find their soul. If they did, we could help in many a case in a very different manner. Psychotherapy as a supplement to purely medical treatment is sometimes much more necessary for the savages than for the whites. ${ }^{40}$

From this perspective, African patients' worldview was the cause of their pathological anxieties. 'Civilizing' their minds was thus a fundamental task for any colonial doctor. Schweitzer assigned psychotherapy a central role in this process. Not proposing a culturally adapted treatment, he aimed to use psychotherapy to bring about a radical change of mindset among African patients towards a worldview based on Western values and conceptions and, above all, devoid of 'superstition'. He justified this version of the 'civilizing mission' with reference to psychiatric imperatives:

Anyone who has ever penetrated a bit into the primitive imagination and knows something about the states of anxiety in which people can find themselves, for whom taboos, unpreventable curses, and effective magic spells exist, is no longer in doubt that we have to attempt to cure them of these superstitions. ${ }^{41}$

39 Barasch to Schweitzer, 3 June 1936, AMs.

40 Schweitzer, Afrikanische Geschichten, 61-62.

41 Ibid., 62. 
In practice, however, Schweitzer's 'civilizing mission' focused on disciplining African bodies through manual labor, rather than on civilizing the minds of his patients by indoctrinating them with Western ideas.

In East Africa in the 1930s, colonial doctors considered the 'clash of cultures' and 'detribalization' as the main causes of mental illness among Africans. ${ }^{42}$ Since the early twentieth century, neurasthenia, for instance, had become 'part of a wider discussion about detribalisation, in which a person's social environment was as important as race. ${ }^{43}$ In Europe the condition was also associated with the stress of 'modernity', but its main trigger for Europeans in the tropics, besides climate, was thought to be separation from 'civilization' and urban life. ${ }^{44}$ In contrast, urbanity represented a key risk factor for mental illness among Africans, as Lynette Jackson argues. Her explanation focuses on her assertion that the mental health of Africans was more likely to be scrutinized in urban environments. ${ }^{45}$ The implication thereof was that men were more likely to be committed to mental institutions. They 'surfaced up', 'because of their formal incorporation into colonial institutional frameworks', while women were more likely to be committed for 'their lack of incorporation' ${ }^{46}$ For the case of Algeria, Nina Studer has coined the term 'hidden patients' for these mentally ill women who would usually not end up in colonial facilities. ${ }^{47}$

Arguing that colonialism produced mental illness and molded its symptoms, ${ }^{48}$ Frantz Fanon warned of the severe effects of colonial rule and colonial psychiatry on colonized individuals. ${ }^{49}$ The tensions that Fanon highlighted between colonial rule and the so-called 'civilizing mission' or between a supposed modernity and mental health had been key concerns for doctors before him and remain prevalent. ${ }^{50}$ Conservative psychiatrists had documented

42 Mahone, 'East African Psychiatry and the Practical Problems of Empire', 47-48.

43 Pringle, 'Neurasthenia at Mengo Hospital, Uganda', 243, 253. Pringle hence links Neurasthenia with education and class, rather than race.

44 Crozier, 'What Was Tropical about Tropical Neurasthenia?'

45 Jackson, Surfacing Up, 70-71.

46 Ibid., 103. At the root of this claim was the argument that 'African women were characterized as normally abnormal, even without the 'civilization' that was needed to unbalance the minds of native men', ibid., 107.

47 Studer, The Hidden Patients,.

48 For a discussion of these arguments, see: Sadowsky, Imperial Bedlam, 3.

49 Fanon argued that depicting the colonized as lazy, criminal, and violent made them resist colonialism in precisely these ways. For a deeper analysis of this argument, see: Studer, The Hidden Patients, 24-25. Frederick Cooper argues that such a simple transfer of 'issues of state sovereignty to personal autonomy' might neglect the 'multidimensional contexts in which personalities are actually shaped'. Cooper, 'Conflict and Connection', 1542-43.

5o For example, René Collignon writes: 'Current economic changes facing Africans and their devastating effects on the traditional family and other solidarity-enhancing groups have 
how colonialism alienated individuals from their self and the surrounding environment, but concluded that the colonized were too slow to adapt, thus bringing mental instability upon themselves. ${ }^{51}$ According to mainstream psychiatric thinking, "the African" in the twentieth century, like the European woman in the nineteenth century, was simply not equipped to cope with "civilization". 52 Many colonial doctors, including Schweitzer, identified two apparent forms of madness among Africans: their innate irrationality and their inability to cope with 'modernity'. Education and economic change were seen as possible remedies for the former, but these came with the disadvantage of inducing the latter. ${ }^{53}$

There is evidence that Schweitzer's understanding of what caused mental illness among his African patients had altered by the 1960s, as had his ideas of how to cure them. In a purported conversation with Dr. Edgar Berman, he discussed how the inherent characteristics that he claimed to have identified among Africans affected their mental health. Schweitzer and Berman talked about a woman known as Mama Sans Nom, one of the most recognizable individuals with an apparent mental illness at the hospital. In many ways, Mama Sans Nom was an atypical patient or inmate, although neither of these designations is appropriate in her case. She was of unknown origin and name, spoke an unidentified language, slept outdoors between two buildings, smoked a pipe, ate worms, regularly sang and danced, walked around without clothes, and came and went as she pleased. ${ }^{54}$ Berman was surprised that she had been diagnosed with dementia 'not, as is generally conceded, resulting from the modern family and the fast sophisticated living we endure, but derived from

forced the individual to face the challenges of competition, including the management of aggressiveness. The development of clinical material over the years seems to emphasize the progressive appearance of guilt in association with increasing modernity'. Collignon, 'Some Aspects of Mental Illness in French-Speaking West Africa', 172. Other authors place more emphasis on the enduring personal impact of emotional trauma suffered during conflict as well as on the effects of macroeconomic decline on the individual. See: Akyeampong, Hill, and Kleinman, 'A Historical Overview of Psychiatry in Africa', 5-10.

51 Vaughan, 'Psychiatry and Empire, Introduction', 1-2.

52 Vaughan, Curing Their Ills, 107.

53 This contradiction has been identified by: Chakrabarti, Medicine and Empire, 135. For a case study, see: Keller, 'Taking Science to the Colonies'. For psychiatrists in Algeria, 'primitivism' was 'a real social problem rather than an intellectual curiosity' (25). According to them, North Africans were inherently mad, a condition that manifested itself especially when faced with 'civilization' (27).

54 Breitenstein, 'Meine Arbeit mit den geistes- und gemütskranken Menschen in Lambarene', 72-73; Oswald, Mein Onkel Bery, 167-68; Stocker, 'Diary 1961-63', 13. 
the most primitive milieu'. ${ }^{55}$ Schweitzer struggled, meanwhile, to reach a definitive diagnosis:

She's obviously not sane; yet she fits into no usual pattern of abnormal behaviour. Perhaps it was the influence of her primitive upbringing and the society she had always lived in that has ameliorated her actions and made her such an (sic) unique mental patient. She may have stranger habits than most of us, but maybe we have worse ones that we tightly control. ${ }^{56}$

Berman's reports are not to be taken at face value, but it was indeed common practice at the time to link tensions between a 'primitive upbringing' and the colonial encounter with mental illness. The quoted conversation illustrates how these discourses were linked with Schweitzer's static and somewhat romanticized picture of Africans and their culture.

In 1961, visitor Andrews was also drawn to the association between intercultural difference and mental health. Having learned from staff members that 'attitude and practice among the native population toward sexuality is [...] almost completely permissive, and without the neurotic guilt and anxiety characteristic of our own culture', Andrews proclaimed his regret that no anthropologist had yet worked in the local area. Referring to Freud, he implied that such permissive sexual attitudes and practices could be expected to lead to a lower rate of 'neurotic anxiety and related symptoms'. He concluded that the area around Lambaréné, which he described as 'still essentially unaffected by the moral concepts of Christianity', 'might yield data that would be of value to psychiatry in theory and application. ${ }^{57}$

When Woodbury and his team of colleagues visited two years later, they maintained that the underlying cause of the professed rise in mental illness among Africans was fairly obvious. They saw the reason for 'the apparent increase in depression among Africans' in 'the internalization of a more individualized superego as detribalization proceeds'. This would result in 'feelings of low self-worth [...] as the native populations become more exposed to an alien but supposedly superior culture..$^{58}$ In their view, members of the Gabonese upper class, such as teachers or church ministers, were especially prone to 'what one would call "transcultural anomie", missing the closeness of belonging to

55 Berman, In Africa with Schweitzer, 64.

56 Ibid., $65^{-66 .}$

57 Andrews, 'Psychiatric Facilities at the Albert Schweitzer Hospital', 527.

$5^{8}$ Woodbury et al., 'Psychiatric Care at the Albert Schweitzer Hospital', 148. 
the tightly knit inner tribal group, yet too Europeanized to accept its restrictions. 59 The logical implication thereof was that 'local culture' constituted a positive influence on mental health. Woodbury and his co-authors were intrigued by the relatively high recovery rates for 'functional psychoses'. They ascribed these to 'permissive child-rearing practices', explaining that 'return from regression is facilitated by the lack of guilt about primary process thinking and activities associated with childhood', while 'in our culture, where punishment and disapproval are common in child rearing, chronicity may be related to guilt about regressed or childlike behavior and thinking'.60

Like Schweitzer and the ethnopsychiatrists, these visiting psychiatrists employed a vocabulary of difference, but at the same time conceded that Africans and Europeans found themselves on the same evolutionary path, albeit at different locations. They spoke of 'regression' or of Christianity having not yet penetrated African culture. In their view, Africans were childlike, their sexual morality retarded. The authors romanticized these societies, imagining an ideal state in which all individuals were at ease with themselves and their surroundings.

Psychiatric care at the Albert Schweitzer Hospital sought to recreate such circumstances. While these visitors insisted on the beneficial influence of 'permissiveness', staff members struggled to find a balance between leniency and control in all areas of hospital life, and especially in the care of the mentally ill. Unlike Schweitzer some twenty years earlier, who had aimed to eradicate African 'superstition', these early 1960s Western psychiatrists recommended preserving patients' cultures in order to maintain their mental health.

Dr. Richard Friedman was, while also having other duties, responsible for psychiatric patients at the Albert Schweitzer Hospital from 1956 to 1969 (see Illustration 38). He was of Hungarian origin and had gone to a Protestant school in Czechoslovakia, after which he converted from Judaism. Nevertheless, he was deported to Auschwitz and Dachau with his parents. After World War Two, he left for Israel where he worked for the army and in hospitals. In summer 1955, he saw a picture of Schweitzer and Dr. Emeric Percy in a newspaper. He recognized the latter from their studies, which encouraged him to reach out to the former, asking if he might serve in Lambaréné. Schweitzer agreed, as Friedman promised to be a long-term option. On several occasions, Schweitzer expressed that he was very satisfied with Friedman on a personal and professional level. ${ }^{61}$

\footnotetext{
59 Ibid., 150.

$60 \quad$ Ibid., 147 .

61 See: Schweitzer to Martin, 6 July 1955, 21 October 1956, 25 November 1956, AMs. No information about Friedman's post-Lambaréné biography could be obtained.
} 


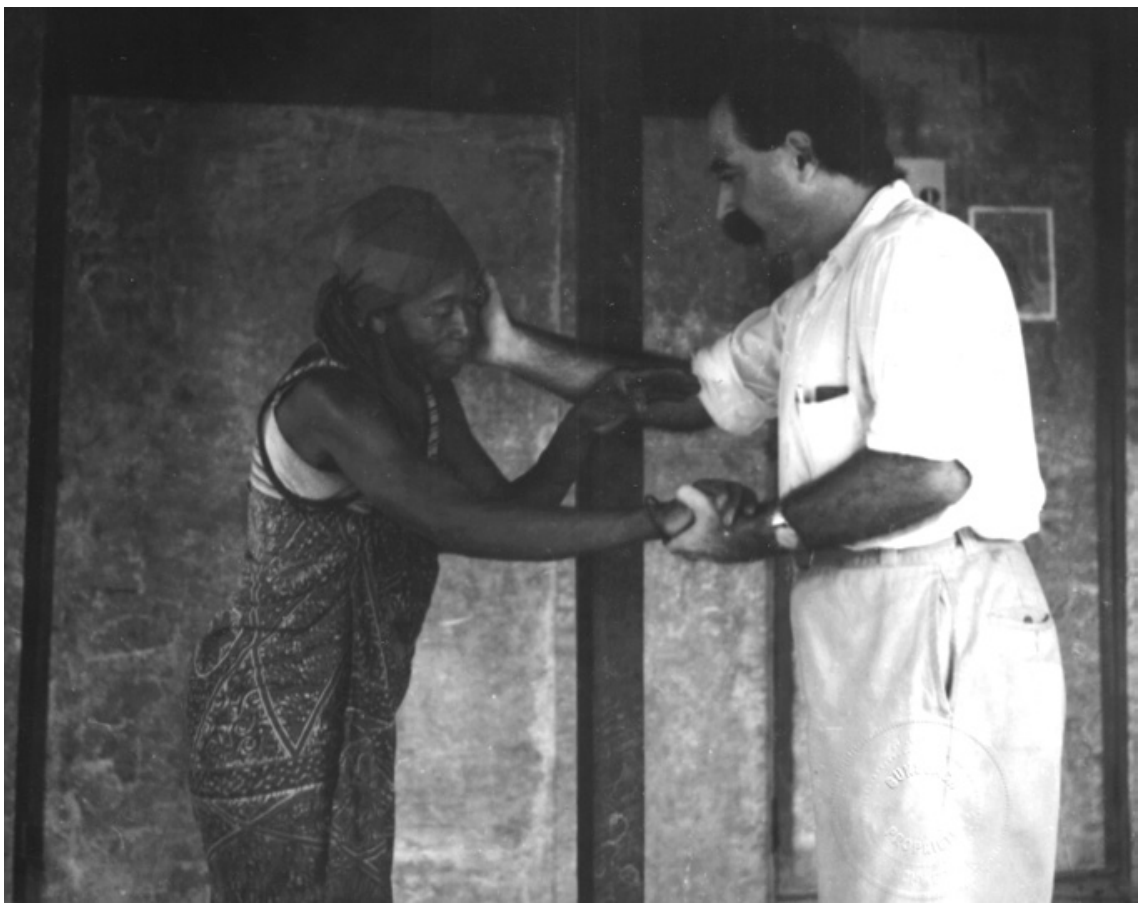

ILLUSTRATION 38 Richard Friedmann and a patient, late 1950S

(C) ARChives CENTRALES ALbERT SCHWEITZER GUNSBACH

Even though Friedman co-authored Woodbury's paper, he was aware of the limits of his understanding of African lifeworlds and expressed thoughts that were similar to the views held by Schweitzer in the late 1930s. After Friedman had unsuccessfully attempted to ameliorate the condition of a psychiatric patient, Gerald Götting, a visiting official from the German Democratic Republic, summarized the doctor's reaction: 'He found the story distressing because he was unable to make progress with his conventional medicine. According to him, it is difficult to help here because it is about "powers", which can hardly be analysed' ${ }^{62}$ For Friedman, one of the most fundamental tasks for a psychiatric doctor was to free the patient from 'various deep-seated fears'. He found this aim extremely difficult to fulfil in Gabon due to what he described as 'the power of magic and the old imaginations of animism, which he thought to be 'overly powerful' in the region. ${ }^{63}$ Successfully treating his patients thus often appeared to Friedman as an impossible challenge, which supposedly was the

62 Günther and Götting, Was heisst Ehrfurcht vor dem Leben?, 173.

63 Ibid., 189 . 
result of their radically different conception of a reality that he did not fully understand in the first place. 'They were talking about things that were much more important to them than any reality. Their entire world is often cruelly different from our own', he said. ${ }^{64}$

Friedman, who believed in intercultural difference and maintained that this had consequences for the treatment of the mentally ill, doubted the effectiveness of Western psychiatric treatment in the case of many of his patients. He thereby contradicted both Woodbury and Andrews, who were remarkably optimistic about their ability to overcome many of the limitations of transcultural psychiatry. Andrews was confident that he could reach a diagnosis by relying on

criteria of the grosser but important sort, such as motor activity, facial expression, tone of voice, ability to relate to examiner and others, response to presumably delusional and hallucinatory material, and resemblance to categories of psychiatric illness encountered elsewhere. ${ }^{65}$

Woodbury and his co-authors went a step further, claiming that 'ordinarily, problems in diagnosing the patients were minimal'. Placing less emphasis on intercultural difference, they underlined that 'we were dealing with people who had already been classed as mentally ill in their own culture'.66 The universality of their outlook becomes even more evident in their descriptions of common therapeutic practices at the psychiatric unit of the hospital. They were convinced that 'the dynamics were familiar, and our treatment concepts were resisted by the natives neither more nor less than at a psychiatric clinic in the United States' ${ }^{67}$ Many of these contradictions of colonial psychiatric care endure even when examining in more detail the practices that were employed to treat the mentally ill at the Albert Schweitzer Hospital. Hospital

Very little is known about colonial psychiatric services in Gabon, or even in AEF as a whole. ${ }^{68}$ In 1923 , Albert Sarraut, France's minister of the colonies,

\footnotetext{
$64 \quad$ Ibid., 169.

65 Andrews, 'Psychiatric Facilities at the Albert Schweitzer Hospital', 525.

66 Woodbury et al., 'Psychiatric Care at the Albert Schweitzer Hospital', 148.

67 Ibid., 149.

68 Neither Headrick nor Mabika provide any information on this topic.
} 
proposed establishing an 'asylum for the insane' in Brazzaville, because doctors at the local hospital did not have anywhere to accommodate the 'poor excited or demented ones' ${ }^{69}$ By 1935, most dispensaries and hospitals in the colony of AEF had buildings to house the 'severe cases'. The médecin général was convinced, however, that 'alongside these severe cases, there are many chronically insane people who live on the fringes of the village and for whom it is essential to create asylums with a special psychiatric service. ${ }^{70}$ In 1950, there was still no 'psychiatry' in the whole colony, only a 'mediocre asylum' in Brazzaville. It was equipped with an electroshock device, which doctors reportedly did not use. ${ }^{71}$

In the early 1930s, Gabon's medical services were underfunded and primarily occupied with the fight against sleeping sickness. When the chef du territoire asked Schweitzer to accommodate psychiatric patients from Libreville, the latter refused because all of his hospital's cells for the mentally ill patients were occupied by insane persons who, according to our predictions, will be staying there for a long time to come. ${ }^{72}$ The government mission that inspected the territory's medical facilities in 1954 made no mention of any psychiatric institution. The hospital in Libreville hosted an unknown number of mentally ill patients, whose living conditions were, according to the mission report, 'certainly below those of ordinary prisoners.' ${ }^{73}$

Given this context, it is unsurprising that not only did the Gabonese colonial government request Schweitzer's assistance in providing psychiatric treatment, but relatives of mentally ill persons also sought to take advantage of these services. Schweitzer treated his first psychiatric patient shortly after his arrival in Lambaréné in 1913, healing her after fourteen days 'for some time at least', as he wrote. ${ }^{74}$ When he recounted this story in his memoirs a decade later, he claimed that 'thereupon the rumour spread that the doctor was a great

69 Sarraut, La mise en valeur des colonies françaises, 437. At the time, the general hospital in Brazzaville had 44 beds for Africans and 16 for Europeans, ibid., 433 .

70 'Rapport médical sur le fonctionnement durant l'année 1935 des services sanitaires et médicaux civils de l'Afrique Equatoriale Francaise'. ZK 005-121, SHD.

71 Baudoux, La situation psychiatrique au Congo et au Ruanda-Urundi en 1950-1951, 8.

72 Schweitzer to Monsieur le Gouverneur de ғом, Chef du Territoire du Gabon, undated, AMs. Schweitzer mentions in this letter that the hospital had a total of only five places for mentally ill patients. The letter must therefore have been written before 1934, when an additional building for psychiatric patients was built.

73 'Rapport fait par M. Petitjouan, Inspecteur de $3^{\text {ème }} \mathrm{Cl}$. de la France d'outre-mer, concernant la vérification $(\mathrm{du})$ Service de Santé Publique du Gabon à Libreville à l'époque du 3 Avril 1954', ZK 005-174, SHD. The hospital in Libreville received unsatisfactory assessments concerning its maintenance and the state of its equipment and financial resources.

74 Schweitzer, 'Notes et Nouvelles de la part du prof. Albert Schweitzer. Deuxième rapport', 19. 
magician and could heal all the insane. ${ }^{75}$ This reputation has persisted into the present. Even André Audoynaud, one of Schweitzer's harshest critics, concedes that he was able to handle agitated cases that not even the police could. ${ }^{76} \mathrm{Au}-$ gustin Emane asserts that 'for my interlocutors, the fact that Schweitzer could calm down those they called the fools was particularly important and was part of the magic of this man'.77 Emane's main informant, Janvier, underlined how 'Schweitzer was even able to be in command of them, while no one else could control them,78 implying not only the police here, but also local healers.

Despite this widespread praise for Schweitzer's natural gift in dealing with mentally ill people, the number of psychiatric cases at the hospital remained relatively low. Prior to 1934, when an additional building was constructed to accommodate what they called 'loud' patients, ${ }^{79}$ there were no more than six beds for psychiatric cases. ${ }^{80}$ By 1950, there were two buildings with six wellventilated compartments each. ${ }^{81} \mathrm{~A}$ decade later, Dr. Jilek-Aall reported that the psychiatric compound consisted of 'three buildings constructed around an inner yard', ${ }^{82}$ offering a total of eighteen rooms, which were all reportedly occupied in $1961 .{ }^{83}$ Like the rest of the hospital, this unit grew rapidly over the following four years. Woodbury and his colleagues then provided the following overview:

The psychiatric service, which is contiguous with the rest of the hospital, consists of four small zinc-roofed huts and one wooden building with heavy bolts that was built 30 years ago to accommodate very disturbed patients. One European nurse assisted by a native male aide runs the service. All patients receive a thorough physical examination and are treated in the general hospital for their numerous somatic ailments: malaria, amaebiasis, intestinal parasites, gonorrhea, and so on. At the time of our study, there were 25 psychiatric inpatients at the hospital -15 men and 10 women. ${ }^{84}$

75 Schweitzer, Zwischen Wasser und Urwald, 48.

$7_{6}$ Audoynaud, Le docteur Schweitzer et son hôpital à Lambaréné, 152.

77 Emane, Docteur Schweitzer: une icône africaine, 159.

78 Ibid.

79 Schweitzer, 'Briefe aus dem Lambarene Februar 1934', 4.

8o Schweitzer, 'Briefe aus dem Lambarene Spital Pfingsten 1931', 8.

81 This detail is taken from the incomplete and muddled 'Statistiques de l'Hôpital' of 1950, $\mathrm{L}-\mathrm{A}-\mathrm{S}_{3}$, AMs.

82 Jilek-Aall, Working with Dr. Schweitzer, 163.

83 Andrews, 'Psychiatric Facilities at the Albert Schweitzer Hospital', ${ }_{224}$.

84 Woodbury et al., 'Psychiatric Care at the Albert Schweitzer Hospital', 146. 
The visiting psychiatrists then provided a statistical analysis of key details about these psychiatric patients. They emphasized that the majority had consulted a 'feticheur' before coming to the hospital, usually together with their family. ${ }^{85}$ At least twenty of the inpatients had been 'admitted involuntarily'. The authors did not specify what exactly this meant, but examples of psychiatric patients being brought to the hospital by force will appear repeatedly in this chapter. Six people had already been treated at the hospital on a previous occasion. Ten patients had been there for between six months and two years, eleven for less than half a year, and four for more than two years. In addition to these inpatients, there were fifteen unspecified outpatients. ${ }^{86}$ At 44 percent, the most common reason given for psychiatric treatment was that the patient presented 'a threat to the community' by being 'assaultive', 'destructive of property', or 'thought to be possessed by evil spirits [...] considered "contagious"'. Another 25 percent 'had become a burden to his family and community', while the remaining $3^{1}$ percent were brought to the hospital due to their 'inability to communicate verbally' ${ }^{87}$ Woodbury and his co-authors did not further specify why they defined such obviously overlapping categories. Their classification highlights the role of the community in defining when a mentally ill patient required hospital care.

The idea that the hospital's psychiatric ward served primarily as a relief for local communities can be discerned from many of the detailed cases found in the sources. Staff and visitors at the Albert Schweitzer Hospital were very concerned about the fate of mentally ill persons who remained in their communities. There are numerous reports from the hospital's initial years that detail mentally ill individuals being chained, restrained with ropes, or even killed in their villages. Schweitzer claimed that the mentally ill could not be confined in a room or cage in their homes because they would always break the weak bamboo bars typically used for this purpose. ${ }^{88}$ In 1925, however, he refused to accommodate more psychiatric cases, arguing that they would disturb other patients at the hospital. 'Hence I have to let them return to their village bonded, where they may be tortured to death, while in my care they may become healthy', he claimed. ${ }^{89}$

\footnotetext{
85 Ibid., 149 .

86 Ibid., 147.

87 Ibid., 148.

88 Schweitzer, 'Notes et Nouvelles de la part du prof. Albert Schweitzer. Deuxième rapport', 19-20.

89 Schweitzer, 'Mitteilungen aus Lambarene. Zweites Heft, 1924-1925', 157.
} 
The account of the nurse Emma Ott from December 1938 invokes similar images of ropes, chains, and a gloomy fate that would await the mentally ill in their villages:

Shortly before lunch, a young, well-grown insane man was brought to us, his legs tied together, his hands tied, and a big chain around his body. In a whisper he spoke to us, with big gleaming eyes. His escorts didn't want to leave him here, they just wanted to get drugs. After a long discussion they left him here. In the village he would have had to be on the chain all the time, here at least he is free in his cell, and if he is calm and not too dangerous, he may sit outside for a few hours under surveillance. ${ }^{90}$

In this particular case, as was typical in other African contexts, the therapy management group did not bring the patient to the hospital for therapy or a cure in the strict sense, but to obtain drugs for temporary relief of symptoms. ${ }^{91}$ From Ott's description, it is unclear whether his escorts agreed to leave the patient at the hospital in order to grant him more freedom of movement, because they started to believe that he would be cured there, and/or because they sought to relieve themselves of the responsibility of caring for him. Meanwhile, Schweitzer and his staff viewed themselves as saviors, believing that their methods of treatment were more humane than the supposedly ignorant approaches resorted to in local villages.

In the 1960s, it was not only the use of ropes and chains in local communities' treatment of the mentally ill that caught the attention of Europeans, but another supposedly common element of (mental) illness in Gabon, namely spirits. By then, psychiatric staff and visitors at the hospital had become eager to obtain a better understanding of patients' mindsets as well as local manifestations of mental illness. Woodbury explained that 'in this region of the world, the mentally ill person is thought to be invaded by spirits', reporting that 'if exorcism, which often includes physical beatings, does not cure the patient, he is abandoned in the jungle to starve or be devoured by wild animals. ${ }^{92}$

The German psychiatrist Christoph Staewen visited Lambaréné in early 1964 in the course of an educational journey through Africa, which marked the beginning of his interest in the continent. In the following years, he would practice as a general physician in Niger, Congo, and Chad. He would also publish memoirs and handbooks, for example on the 'cultural and psychological

90 Ott, 'Natur, Mensch und Tier', 138-39.

91 Jackson, Surfacing Up, 11.

92 Woodbury et al., 'Psychiatric Care at the Albert Schweitzer Hospital', 145. 
conditions' of 'cooperation with Africans'.93 In a text on his stay in Lambaréné, he equated, like Woodbury and his colleagues, Gabonese therapies for mentally ill individuals with 'exorcisms'. Staewen though did not suggest that any beatings occurred during therapeutic ceremonies, but still described the practices as being conducted with considerable force.

They get drugs that whip up all their senses. By forcing the sick to dance for days or weeks, one tries to drive out the 'evil spirits'. Or they are tied up in a pit so that they can only see a piece of heaven and their food is thrown down. And often it is only then, when the local medicine man has to acknowledge that he is powerless, that the patient is taken to hospital. Maybe the 'docteur' will help him...94

For Staewen, the inevitable culmination of the local quest for therapy was treatment at the Albert Schweitzer Hospital. He did not provide any details on where he had obtained his information, but mentioned having exchanged with Ruth Breitenstein, who served at the hospital on seven occasions from 1957 to 1966 and was responsible for caring for the psychiatric patients during her later stays. In her memoir, Breitenstein would use almost identical words when describing how the mentally ill were treated in their villages, also without disclosing her sources..$^{95}$

A number of female staff members from the hospital who secretly attended dance events in the 1960 os recalled them in a similar manner and were fascinated by their 'aggressive' side. Some perceived them as healing rituals, ${ }^{96}$ while others did not. ${ }^{97}$ Louise Jilek-Aall provides an especially detailed account of such an event. One day, she observed 'noticeable excitement among the Africans at the hospital'. In response to her persistent requests for information, they told her of 'a big feast at a village' and a 'famous medicine man who was expected to come'. The auxiliary Gustave Manyihou invited her to 'come and

93 Staewen, Kulturelle und psychologische Bedingungen der Zusammenarbeit mit Afrikanern.

94 Staewen, 'Die geistes- und gemütskranken Patienten des Spitals Lambarene 1964', AMs. A translated and abridged version of this text was subsequently published as: Staewen, 'Les malades mentaux de l'hôpital de Lambaréné'.

95 Breitenstein, 'Meine Arbeit mit den geistes- und gemütskranken Menschen in Lambarene', 71. Breitenstein had not undergone formal nursing training, but had worked with mentally ill patients in Switzerland.

96 Group Interview Speicherschwendi. The nurse Anderegg referred to the ceremony as a 'death dance'. She found it 'frightening', because all the participants were drunk and aggressive. Interview Elisabeth Anderegg.

Stocker, 'Diary 1961-63', 18. 
see for yourself $[. .$.$] you could observe a medicine man at work. { }^{\prime 98}$ Together with Eric, the hospital's carpenter, Jilek-Aall stole away on the night of the event and canoed to the village. Believing that she had spotted Manyihou, 'oblivious' to their presence, among the dancers, Jilek-Aall described a transformation: he was no longer the 'submissive orderly', but now a 'wild man, unrestrained and disinhibited in his emotional expressions; strangely fearsome'.99 The 'medicine man' appeared in a mask and approached the visitors, clearly making a point of indicating their presence. When the dancing and singing intensified, Jilek-Aall became 'really scared'. A young man, 'obviously seriously ill', appeared in the middle of the circle of dancers that had formed. ${ }^{100}$ The man in the mask proceeded to touch the sick man, after which the latter seemed to fall into a state of unconsciousness. He was then taken into a 'compound' out of Jilek-Aall's sight, after which she and Eric were asked to leave.101 Manyihou came to work at the hospital the following day, but made no mention of the previous night's events.

For Jilek-Aall, the episode betrayed 'how little did we actually know'; she saw a 'different world [...] of which I could never be a part'.102 However, her description reveals her fascination with the strangeness of the event. Moreover, violence pervades her narrative to a much lesser extent than in other accounts; instead, she draws attention to the communitarian aspects of local therapeutic practices. For a more detailed interpretation of such practices, we can turn to a text by Dr. Munz in which he describes another local treatment method.

Munz was in regular contact with Marcelline Nyndounge, a Fang woman who ran a 'traditional hospital village' some two hours by rowing boat from the Albert Schweitzer Hospital. This 'hospital village' was called 'Meteghe', which Munz translates as 'earth' or 'soft'. Contrary to this name, he observed 'extremely hard phases of treatment' there. ${ }^{103} \mathrm{~A}$ patient's stay, which typically lasted for several weeks, culminated in him or her being laid into a ritual grave that the patient then destroyed. All the other patients participated in this ceremony, singing and dancing throughout. Thereafter, Nyndounge talked to the patient for several hours. The goal of this consultation, 'during which (the patient) is soon beaten by Marcelline in the face, soon quietly and motherly cheered up and comforted', was to find the cause of the illness. Munz did not list what causes were considered, but he suspected that, unlike for other healers he had

\footnotetext{
98 Jilek-Aall, Working with Dr. Schweitzer, 117. No information could be obtained on Eric.

99 Ibid., 120.

$100 \quad$ Ibid., 123.

101 Ibid., 124

102 Ibid., 127.

103 Munz, Albert Schweitzer im Gedächtnis der Afrikaner und in meiner Erinnerung, 127.
} 
heard of, blaming someone else was not Nyndounge's central concern; hence her ways were 'soft'. ${ }^{104}$ When the cause was eventually discovered, the other patients resumed their singing and dancing. ${ }^{105}$ The fundamental importance attached to finding the cause of a disorder was also emphasized by anthropologists studying the Mitsogho people of southern Gabon, who insisted that most local therapies were to bring about an 'individual and social re-equilibrium'.106 Nyndounge, in contrast, was primarily concerned with ensuring that her patients returned home in a cured state.

These more detailed accounts of Jilek-Aall and Munz, as well as the following one by the anthropologist Fernandez, suggest a different interpretation of beatings during treatment than the one put forward by European visitors such as Staewen. African healers, family members, and patients shared another conception of such therapeutic violence. They regarded beatings administered in the context of treatment as fundamentally distinct from those committed as acts of wanton violence. They were aware that 'the struggle against evil and the combating of misfortune is nowhere a child's play', to use Munz' words. ${ }^{107}$

Many of the motifs identified in the above accounts - chains and ropes, beatings, spirits, but not dancing - also make an appearance in Fernandez's detailed description of Antoine, a Fang man who would have been considered a psychiatric case by Europeans. Antoine's example, which reveals much about Fang conceptions of (mental) health, provides a basis of comparison for the patients whom we will encounter later in this chapter. A key difference between Antoine's story and comparable accounts in sources relating to the Albert Schweitzer Hospital is that he was never admitted to a hospital. In his case, this option appears to have not even been considered, suggesting that it was reserved for specific afflictions.

Antoine started to jump on rooftops and to babble incomprehensibly. He expected mail arriving from France, wanted to build a European-style house, and predicted that he would become 'as rich as a white man'. He annoyed and ridiculed almost everyone in his village, but his fellow villagers remained curious about his repeated prophecies. When he started to swing a long stick at people in the village, his brother tied him up and confined him to bed for a day. ${ }^{108}$ Villagers agreed that Antoine was "heartsick" [...] the concept of general application to those disturbed in their thinking about themselves, about

\footnotetext{
104 Ibid., 140.

105 Ibid., 131.

106 Otto Gollnhofer and Roger Sillans, 'Phénoménologie de la possession chez les Mitsogho (Gabon). Rites et techniques', 742.

107 Munz, Albert Schweitzer im Gedächtnis der Afrikaner und in meiner Erinnerung, 128.

108 Fernandez, Bwiti, 188. Fernandez also provides valuable information in his footnotes.
} 
others, and about the visible world in which men lived'.109 According to Fernandez, this was a state that manifested itself in either an 'excess of activity' or an 'excess of tranquility',110 either way representing a malfunction of the heart, 'the Fang organ of perception, intellection, and balanced judgment'.111 Proper functioning of the heart was considered crucial, Fernandez argues, because Fang individual and societal well-being derived from the state of 'oneheartedness', namely 'an orderly preparation in the discharge of all things' that manifested itself in 'general integrity of feeling and thought in human affairs'.112 The categorization of Antoine's illness, as well as its cause, was disputed among villagers. As often occurred in relation to other illnesses, some believed that Antoine may have been the target of somebody else's spiritual aggression. Alternatively, other villagers suspected that the disorder might have been caused by Antoine's own aggression, such as his breaking of a taboo, or him challenging his own Evu. ${ }^{113}$

As long as Antoine did not disturb the sense of peace and order in the village, he enjoyed considerable freedom to indulge in his extraordinary behavior. As soon as he threatened the village's calm though, he was forced to undergo treatment. This was, according to Fernandez aimed at 'reunification, knitting together, the making as one', which was achieved by 'returning men, and the village affected by their actions, to appropriate activity or tranquility by calming or animating demons or ancestral spirits, whichever be involved'.114 Antoine's brother enlisted the help of a 'woman herbalist from a nearby village'. She 'determined that his witchcraft spirit was twisting his heart, and she treated him with a concoction to calm it. She beat him with leaf branches dipped in hot herbal infusions' ${ }^{\prime 15}$ Antoine's therapy did not have immediate effect. He did, however, manage to go to Oyem, where he resumed his former job as a tailor. He would return to his village one year later in an 'apparently normal' state. ${ }^{116}$

Woodbury and his colleagues likewise noted that the impact of a person's mental state on social life was decisive in local diagnoses. 'As in most primitive cultures, a person is considered mentally ill only when his defense mechanisms

\footnotetext{
109 'Nkukwan nlem' (N) and 'Nkôkôm nlem' (F) were the Fang concepts that Fernandez rendered as 'heartsick', 190.

110 Ibid., 194.

111 Ibid., 190.

112 Ibid., 192.

113 Ibid., 190.

114 Ibid., 195 .

115 Ibid., 189 .

116 Ibid.
} 
are threatening or burdensome to the community', they wrote, further specifying that 'insanity is classified by the Gabonese into two broad categories: fou furieux and fou doux.'177 This classification recalls Fernandez's dichotomy between 'excess of activity' and 'excess of tranquility'.118 These categories found their equivalent at the Albert Schweitzer Hospital in the form of the 'loud' and 'quiet' wards in which psychiatric patients were segregated. As discussed in Chapter 1 and suggested by Munz, the idea of balance, so persistent in these psychiatric cases of the early 1960s, might misrepresent local conceptions of disease. Psychiatric cases at the hospital prove that mechanisms of attack and defence were also at play.

\section{Treating the Mentally Ill at the Albert Schweitzer Hospital: Drugs and Community}

The 1961 case of Leo, a kitchen servant at the Albert Schweitzer Hospital, illustrates many facets of psychiatric care at the institution. His story, as narrated by Dr. Jilek-Aall, started when his wife suffered a miscarriage after he had beaten her. ${ }^{119}$ Her brother then demanded money from Leo to compensate for the death of his unborn nephew. After Leo refused to pay, his brother-in-law placed a curse upon him. Seeking protection, Leo relocated to the hospital grounds, but soon started to behave strangely. After claiming that he was being attacked by the Devil, Leo was moved to one of the bare cells for 'loud' patients in the psychiatric compound. By this stage, his state was such that 'no amount of medicine could pacify him and it was such a battle to subdue him for an injection that we gave it up, since it did not seem to help.' ${ }^{120}$ When Leo eventually calmed down, the doctors were compelled to force-feed him because he refused to eat for fear of being poisoned. Jilek-Aall was curious about the cause of Leo's condition and sought the opinions of African personnel. She did not specify with whom she spoke, but the answers that she received varied. Some people believed that the Devil was responsible; others thought that

Leo might have been poisoned and worried that in-laws might try to sneak in harmful substances; others assumed ancestral spirits were taking revenge for the unborn child whose death he had caused; some

\footnotetext{
117 Woodbury et al., 'Psychiatric Care at the Albert Schweitzer Hospital', 148.

118 Fernandez, Bwiti, 194.

119 Jilek-Aall, Working with Dr. Schweitzer, 154-62.

120 Ibid., 164.
} 
believed that Leo was bewitched and that an evil spirit possessed him. They told me that such a spirit had the shape of a bird and would lodge in a person's chest. ${ }^{121}$

Fearing that Leo would die, his relatives, including his brother-in-law, appeared to encourage and forgive him, but to no avail. ${ }^{122}$ Ultimately, however, a cure did arrive in the form of what Jilek-Aall described as a sort of miracle healing. Schweitzer, reminding the reader of Jesus, simply talked to Leo, after which the latter recovered and soon returned to work. 'When later asked about his illness, he would give us an embarrassed smile and answer that he could not remember anything of it at all', Jilek-Aall concluded the story. ${ }^{123}$

The treatment for psychiatric patients at the Albert Schweitzer Hospital consisted of three key pillars. Patients were individually confined in small and solid single cells, particularly when they were severely agitated; they received drugs to reduce the number of such episodes; and, unlike Leo, they took part in what can be considered to have been a form of occupational therapy. The latter aimed to recreate a sense of community and belonging, the loss of which was assumed to be an essential cause of their mental illness.

In Gabon, some missionaries had used drugs to calm down mentally ill patients before Schweitzer's arrival in Lambaréné. ${ }^{124}$ During his first stay, Schweitzer administered tranquilizers to keep psychiatric patients quiet at night; it had annoyed him that they had disturbed the other patients and that he had had to get up at night to administer these injections. ${ }^{125}$ The first mentally ill person he treated features prominently in Schweitzer's writings. Three months after his arrival, he had been called to a village, where he found the woman tied to a tree:

I gave the order to untie her; people obeyed only reluctantly and with fear. As soon as the woman felt free, she threw herself on me to tear off my lantern and break it. The people around us ran away screaming. I took the woman by the wrists and succeeded in having her sit and calm her

\footnotetext{
121 Ibid., 165. The bird-shaped spirit is possibly a reference to the Evu. See also Chapter 2.

122 Ibid., 167.

123 Ibid., 170.

124 Morel, 'Au Gabon avant l'arrivée du Docteur Schweitzer', 187. Morel was a missionary with the PEMS. He arrived in Lambaréné in 1908 and reported administering 'a potion of bromide and chloral'.

125 Schweitzer, 'Notes et Nouvelles de la part du prof. Albert Schweitzer. Deuxième rapport', 18.
} 
down. She lent her arm to a shot of scopolamine and morphine and soon fell asleep. ${ }^{126}$

She was subsequently taken to the hospital, where she received further doses of scopolamine and morphine. Schweitzer diagnosed her with a 'manic excitation, which came back periodically', treating her with bromide and fortifiers, in response to which the woman 'calmed down very quickly and was cured - for a time at least - after a few days'.127 Schweitzer thus acknowledged that this method might not deliver long-term results and admitted the probability of relapses. Moreover, he learned shortly thereafter that it did not always work. Having declared the woman cured, he attempted to treat a man exhibiting similar symptoms by employing the same methods. But Schweitzer's first auxiliary, Joseph Azoawanié, suspected poisoning, predicting that the patient would die, as indeed he did after fifteen days. ${ }^{128}$ Scopolamine and morphine were still used at the hospital in the late 1940 s to treat mental illness, at least in cases of 'extreme necessity', ${ }^{129}$ but no further details on their application are provided in the sources.

Drugs remained an important instrument in the treatment of mentally ill patients at the hospital. In 1955, Schweitzer placed high hopes in Plexonal Forte, a barbiturate manufactured by the Swiss pharmaceutical company Sandoz. In words that recalled his enthusiasm for drugs used to treat infectious diseases, he wrote to Sandoz that 'it will be a redemption for them (the mentally ill) as it will be for us if we can calm them down with these new medicines. In the heat that reigns here, one cannot keep the mentally ill trapped, as in Europe.' 130 When Francis Catchpool, an English doctor who served two terms in the late 1950s, ordered a supply of medications two years later, he requested paraldehyde for psychiatric patients, a standard sedative. ${ }^{131}$ Neither Schweitzer nor Catchpool listed among their orders any of the new antipsychotics, which had become the preferred treatment across the world for a wide range of psychiatric illnesses by the mid-1950s. ${ }^{132}$

\footnotetext{
126 Ibid., 19 .

127 Ibid.

128 Ibid., 20.

129 Schweitzer to Alliez, 27 November 1948, AMs.

130 Schweitzer to Sandoz, 17 January 1955, AMS. Italics mine.

131 Catchpool to Schweitzer, undated, probably 1957, AMs.

132 The first antipsychotics, chlorpromazine, was officially released onto the French market at the end of 1952. See: Ban, 'Fifty Years Chlorpromazine'; López-Muñoz et al., 'History of the Discovery and Clinical Introduction of Chlorpromazine'.
} 
Schweitzer first mentioned these in March 1960, when he thanked Sandoz for having delivered a supply of Melleril. The company had sent this antipsychotic two years after its launch as a 'test preparation' to Lambaréné, with Schweitzer replying that it 'has proven to be excellent'. ${ }^{133}$ When Andrews visited in June of the following year, he noted that the hospital had several antipsychotics in stock, but that the staff had never been sufficiently confident to administer them without the advice of a specialist. Now, under Andrews' expert supervision, they were willing to test these drugs. On the trials, Andrews wrote:

It was conceived essentially as an experiment to see how the native patients would react to the medication and whether it would be possible to quiet the agitated enough to permit some or all of them to join the others outside during the day for the purpose of returning them sooner to the community. ${ }^{134}$

When Woodbury and his colleagues visited the hospital in December 1964, they claimed that Melleril was the only antipsychotic in use. ${ }^{135}$

This short overview of the drugs used to treat mentally ill patients at the hospital suggests that the doctors adopted a trial-and-error approach in line with those described in the previous chapter in relation to leprosy and dysentery. This approach also corresponds to the history of antipsychotics in Europe. ${ }^{136}$ Medical personnel at the Albert Schweitzer hospital administered these drugs in order to tranquilize patients and ensure their own safety as well as that of other patients. Pharmaceutical treatment, it was argued, would enable psychiatric patients to leave their cells occasionally. It was also hoped that it would facilitate the introduction of forms of occupational therapy based on community-building. The sedative effects of the drugs were appreciated by staff and patients' relatives alike, but patients frequently resisted their application, as we have seen in the case of Leo. In the 196os, African auxiliaries

133 Schweitzer did not specify when the hospital had received the drug, nor did he provide any details on subsequent trials. Schweitzer to Sandoz, 20 March 1961, AMs. The letter might be archived among the correspondence of Fritz Dinner. On Melleril, see:; Zeller, Globalisierungsstrategien - Der Weg von Novartis, 314.

134 Andrews, 'Psychiatric Facilities at the Albert Schweitzer Hospital', 525. Marplan, an antidepressant, was given to five patients who 'appeared depressed', Trilafon to five supposedly 'disturbed patients'. After four days, Andrews was cautiously optimistic about the results, but did acknowledge that the trials were of little wider value given their limited extend.

135 Woodbury et al., 'Psychiatric Care at the Albert Schweitzer Hospital', 146.

136 Meier et al., Testfall Münsterlingen. 
employed the following 'trick' whenever psychiatric patients attempted to evade an injection:

They would arm themselves with patience and chat with the patient to calm him down. Then they would ask him to put his hand through a hole to grab an object that interested him. One of them took the opportunity to hold this arm and the other to do the injection. ${ }^{137}$

African auxiliaries had a crucial role to play in the care of psychiatric patients. This was because the doctor responsible for psychiatric cases was required to spend a large amount of time in other wards, and it was not until the early 1960s that a European nurse was assigned the dedicated role of caring for the mentally ill. ${ }^{138}$ Most frequently discussed in the sources is Jean Mendoume, who began working at the hospital in 1924 (see Illustration 39). ${ }^{139}$ European nurses who worked with Mendoume praised him on several occasions. Jeanette Siefert, for example, claimed that he noticed 'earlier than anyone else when a seizure of raving madness was coming; he managed that the already somewhat rebellious man handed him the knife and let himself be locked up in his chamber'.140 Besides illustrating that safety measures were not always strictly enforced at the hospital, this statement demonstrates the critical function fulfilled by African auxiliaries as middle figures in this transcultural setting. Ironically, Mendoume himself would be confined in one of the hospital's cells for psychiatric patients after an episode of 'senseless drunkenness', as Schweitzer explained to his secretary. ${ }^{141}$ The way in which Schweitzer narrated this story suggests that this was not the first time that Mendoume had committed such misdemeanor; nevertheless, he played too crucial a role in the psychiatric unit for Schweitzer and his team to consider dismissing him from his job.

Staff's main responsibility in the psychiatric unit was, after administering drugs and keeping them calm, to ensure that their patients had enough work

137 Nyama, 'La dame tout de blanc vêtue et son trousseau de clés', 48.

138 Woodbury et al., 'Psychiatric Care at the Albert Schweitzer Hospital', 146. In the 1930s, the one nurse responsible for caring for the mentally ill was also required to dress ulcers, monitor the women who manufactured palm oil, buy and distribute food, and oversee the maintenance of general hygiene at the hospital. See: Schweitzer, 'Briefe aus dem Lambarene Spital November 1935', 5-6.

139 See the 1962 'liste des employés les plus anciens, proposés pour une décoration', which is kept in a folder entitled 'affaires concernant le personnel indigene' in a box labeled 'divers' in the cellar of the AMs.

140 Siefert, Meine Arbeitsjahre in Lambarene 1933-1935, 57.

141 Schweitzer to Martin, 27 June 1937, AMs. 


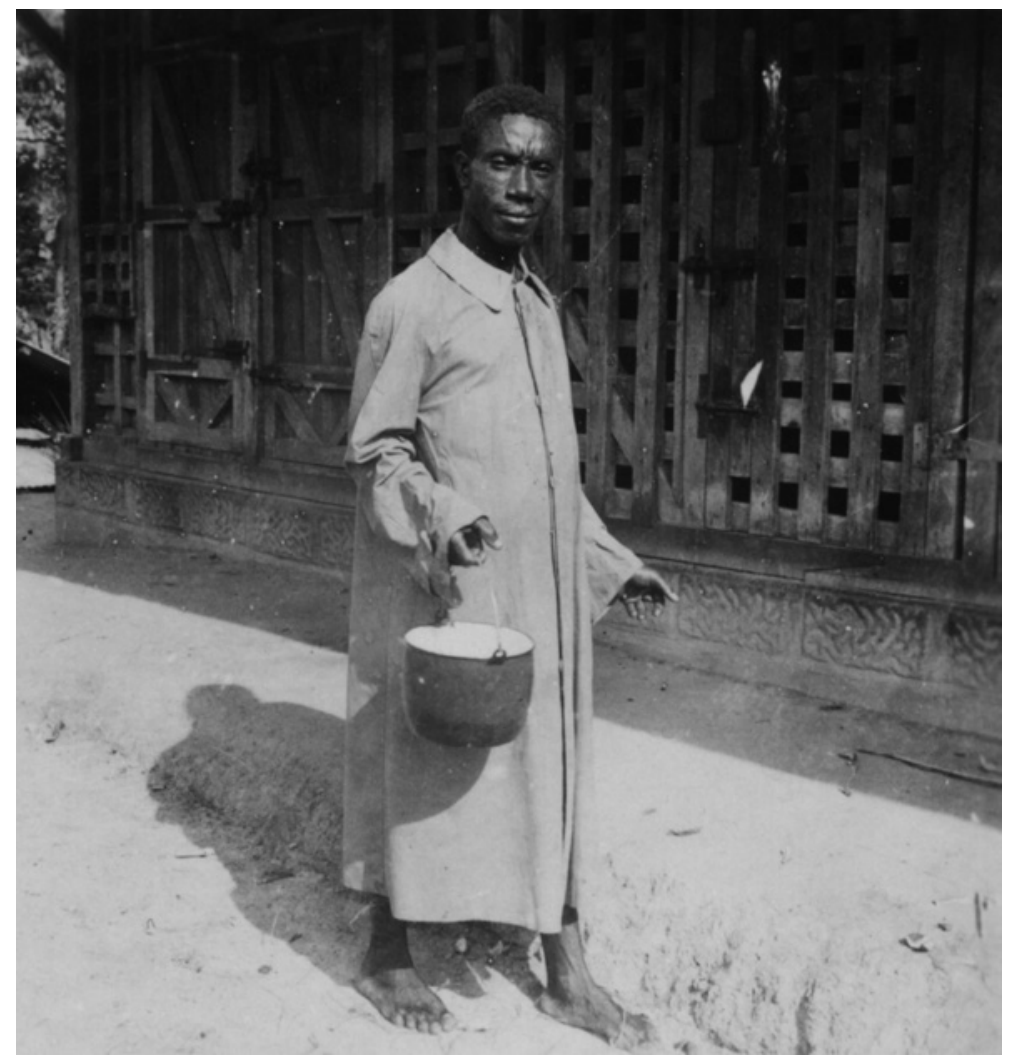

ILLUSTRATION 39 Jean Mendoume in front of the psychiatric ward, ca. 1934

(C) ARCHIVES CENTRALES ALBERT SCHWEITZER GUNSBACH

to keep them occupied. This form of occupational therapy, which represented a key pillar of what Schweitzer perceived as his 'civilizing mission', was consistent with the hospital-wide practice of engaging everyone in labor, patients and their relatives or visitors alike. For Schweitzer, work ethic and an ethicsbased sense of community - the latter, however, under threat from the spread of individualistic materialism - were standout features of 'Western civilization'.

Fostering a communal work ethic, he believed, was thus the logical remedy for those who had been negatively affected by other aspects of this very 'civilization'. In 1927, Mombo, 'an epileptic who also often has seizures of mental disorder', worked as one of Emma Haussknecht's assistants. She was unimpressed by the efforts of the two psychiatric patients who were her assistants, bemoaning that 'I can hardly count on them when it comes to work, especially not on Mombo. ${ }^{142}$ Five years later, the nurse Emilie Spoerri was more satisfied with the work performed by Antoine, a psychiatric patient who assisted her

142 Albert Schweitzer, 'Neues von Albert Schweitzer Juli 1927', 2. 
with the distribution of food and other unspecified tasks. ${ }^{143}$ In the 1930s, mentally ill patients who were categorized as 'quiet' produced wood carvings on a regular basis. ${ }^{144}$ None of these activities was sufficiently productive to play an important role in the hospital economy; psychiatric patients were put to work to keep them occupied.

By the 196os, occupational therapy formed a more integral part of the hospital's psychiatric treatment regime, now also incorporating more productive tasks such as the manufacturing of rope from pineapple fiber or the making of fishing nets. ${ }^{145}$ The main activity for psychiatric patients, however, had become working in the hospital's vegetable garden, which provided food for European staff and patients (see Illustrations 40,41 , and 42 ). ${ }^{146}$ In this way, mentally ill patients acquired some economic importance and partly replaced the wage laborers whom Schweitzer had employed during World War Two. ${ }^{147}$

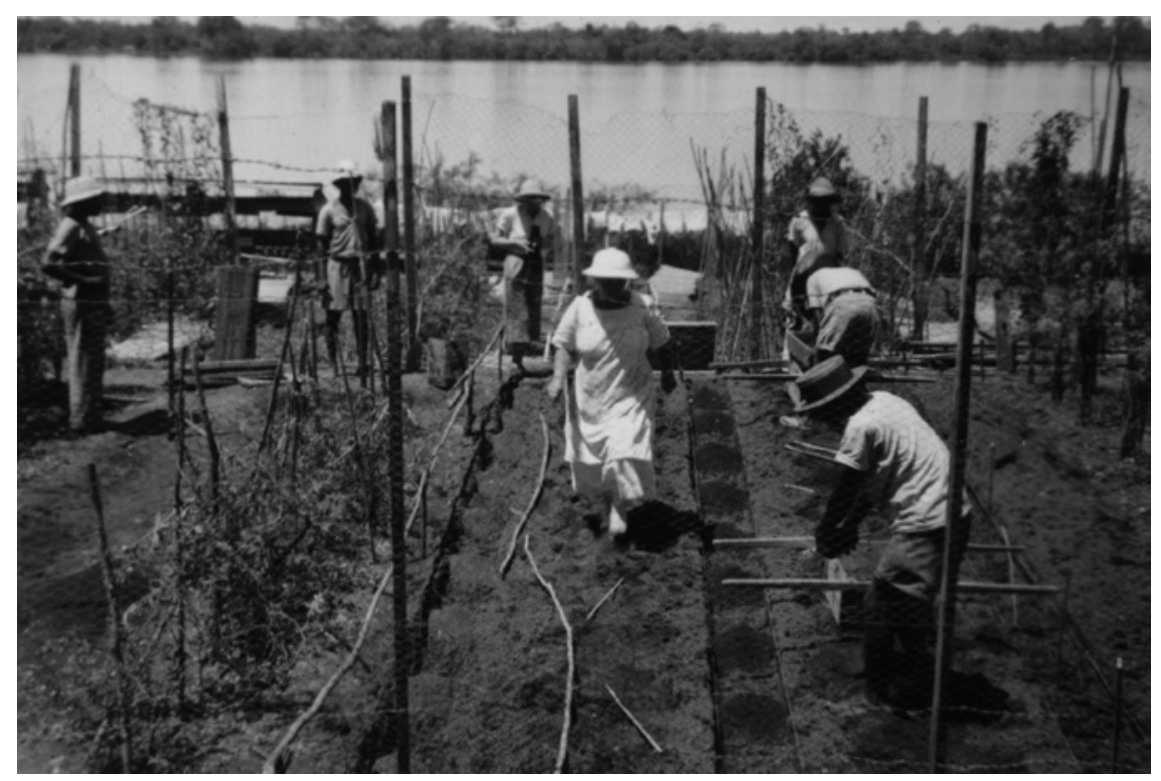

ILLUSTRATION 40 Emma Haussknecht and laborers in the vegetable garden, ca. $195^{\circ}$

(C) ARCHIVES CENTRALES ALBERT SCHWEITZER GUNSBACH

143 Spoerri to Schweitzer, 6 June 1932, AMs.

144 Siefert, Meine Arbeitsjahre in Lambarene 1933-1935, 57.

145 Andrews, 'Psychiatric Facilities at the Albert Schweitzer Hospital', 525; Group Interview Speicherschwendi. It is unclear what happened to these objects.

146 Breitenstein, 'Meine Arbeit mit den geistes- und gemütskranken Menschen in Lambarene', 72; Interview Marianne Stocker.

147 Schweitzer to Seaver, 'Notes Sur l'Hôpital 1939-1945', AMs. In this letter, Schweitzer provides a detailed overview of the hospital at the time of World War Two. Verena Schmid, 


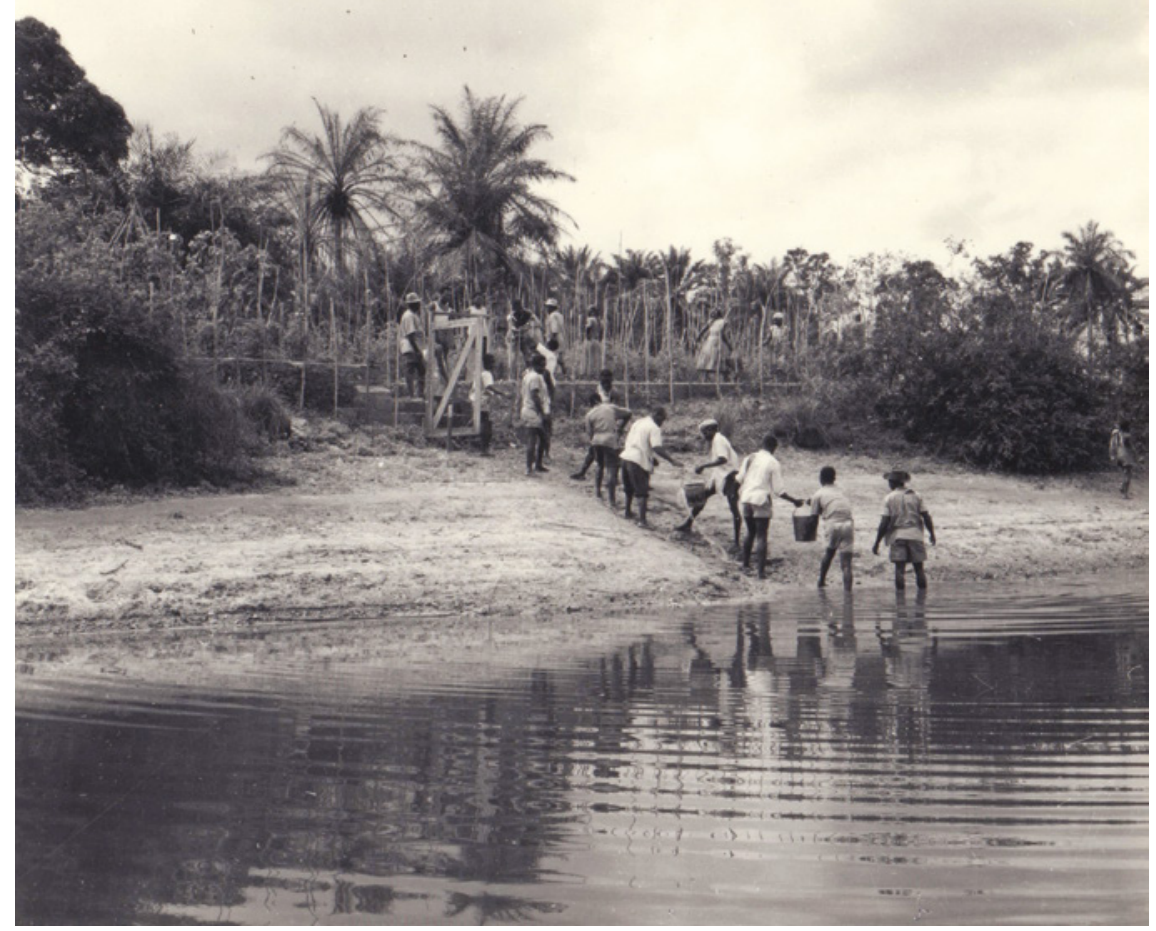

ILLUSTRATION 41 Watering the garden, ca. $195^{8}$

(C) ARCHIVES CENTRALES ALBERT SCHWEITZER GUNSBACH

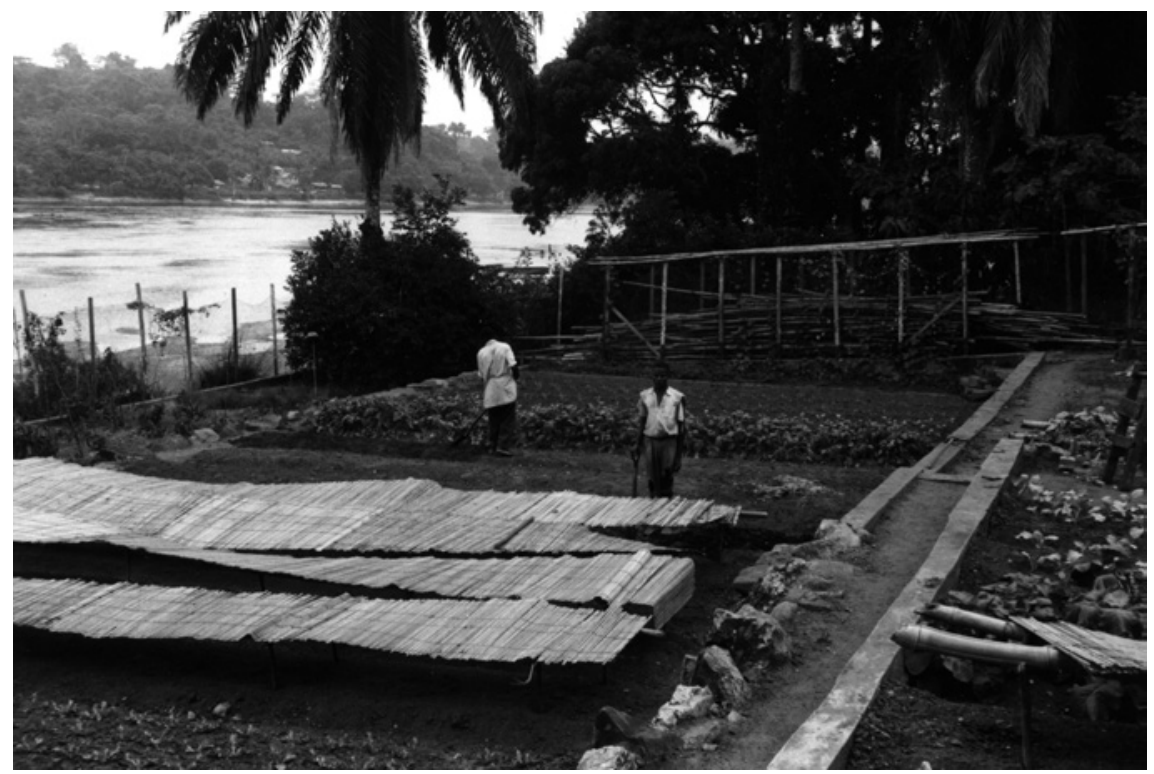

ILLUSTRATION 42 The vegetable garden and two workers, undated (C) ARChives CENTRALES ALBERT SCHWEITZER GUNSBACH 
In accordance with the theory that the trend towards individualization imposed by 'Western civilization' made Africans mentally ill, treatment of psychiatric patients at the hospital aimed to restore their sense of belonging by recreating a new community for them. Many patients who came to the hospital with a mental disorder lived in the somewhat urbanized area of Lambaréné, where they worked for the colonial administration or in the capitalist economy, for example as traders or wage laborers. Psychiatrists posited that these patients had lost the connections to their communities in this rapidly changing environment, which disturbed their personal identity and inner peace.

The one case study provided by Woodbury and his colleagues demonstrates this argument. A successful businessman from Cameroon whom the authors called J.D. was treated at the hospital for malaria, intestinal worms, amoebic dysentery, and for gonorrhea, the disease that had led his wife to leave him.J.D. continued to complain of 'aches all over'. He also had dreams of having sexual intercourse with European women or being chased by a man with a gun. He was eventually diagnosed with a 'psychoneurotic depressive reaction', which Woodbury and his co-authors attributed to 'a longing for the tribal clan and family ties', a state that he apparently rediscovered at the hospital. They argued that he 'was loath to give up the physical symptoms that were his admission ticket, so to speak, to the hospital community'.148 J.D. exemplifies many of the issues discussed in the historiography of mental illness in colonial Africa. He 'surfaced up' as a result of living near Europeans; he was also 'insufficiently other' due to his participation in the capitalist economy as a businessman and his desires for European women. At the Albert Schweitzer Hospital, he was thus to be reintegrated into a community of Africans incorporating mentally ill patients from all local ethnic groups. Unlike the relatives of other patients, psychiatric patients' family members were not welcome to stay at the hospital and form part of treatment. ${ }^{149}$

J.D. was not the only patient undergoing treatment for a mental disorder who reportedly expressed a wish to remain at the hospital. In his 1964 text, Staewen discussed a number of patients, one of whom was Mongale, a former 'medicine man.' ${ }^{150}$ The 'initial drug- and age-related state of confusion' for which he was originally treated soon diminished, in Staewen's view chiefly as a

who was responsible for the vegetable garden in the early 1950s, wrote extensively about her successful harvests, but never mentioned having any assistants.

148 Woodbury et al., 'Psychiatric Care at the Albert Schweitzer Hospital', 150.

149 Ibid., 146-47. The visiting psychiatrists received the following explanation for this: 'relatives were suspected of giving the patients 'bitter root', a potion containing an alkaloid with effects similar to LSD-25, as the patients frequently became psychotic again after a visit'.

150 Staewen, 'Die geistes- und gemütskranken Patienten des Spitals Lambarene', AMS, 3. 
result of occupational therapy. ${ }^{151}$ Mongale soon felt at ease at the hospital. 'I am at home here', he said according to Staewen, 'where should I go? My brothers and sisters are no longer alive and my children hardly know me anymore. I want to stay here and work. ${ }^{152}$ Following Staewen's narrative, the hospital provided mentally ill Africans with a second family that stood in for the village communities whose absence from their lives had made many of them sick in the first place. In this analogy, the European nurse in the psychiatric ward, a role fulfilled by Ruth Breitenstein at the time of Staewen's visit, acted as a substitute mother:

Under her empathetic guidance, which can and must sometimes be quite firm, the patients form a real group. They become a family with their 'mother', although they are thrown together from very different races, tribes and ways of life. Despite being deeply affected by their own illness, the sick develop a very simple but very effective sense of togetherness which cannot be observed in Europe among comparable patients. ${ }^{153}$

Staewen expanded on these claims by recounting the story of another agitated patient, a woman who had been brought to the hospital tied up in ropes. The patient had been immediately confined in a cell - 'so she can't damage herself or escape into the nearby jungle' - where she received an unspecified first dose of drugs. After two days, she was allowed to leave her cell to join her fellow psychiatric patients for a meal. They welcomed her warmly and offered her food, which she accepted despite her fear of being poisoned. ${ }^{154}$ According to Woodbury, the 'cooperative preparation of breakfast and lunch' was the 'main activity' that fostered this familial community spirit. ${ }^{155}$ When Staewen's patient got upset again, refused her medication, and stripped naked, her peers were more successful in calming her down than Breitenstein. ${ }^{156}$

These Western observers imagined the existence of a community within the hospital, especially among African psychiatric patients and their European staff. As a key component of the hospital's psychiatric treatment regime, community-building was an adaptation of the colonial 'civilizing mission' to the circumstances and requirements of psychiatric care. It was aimed at spreading specific aspects of European 'civilization', such as an appreciation

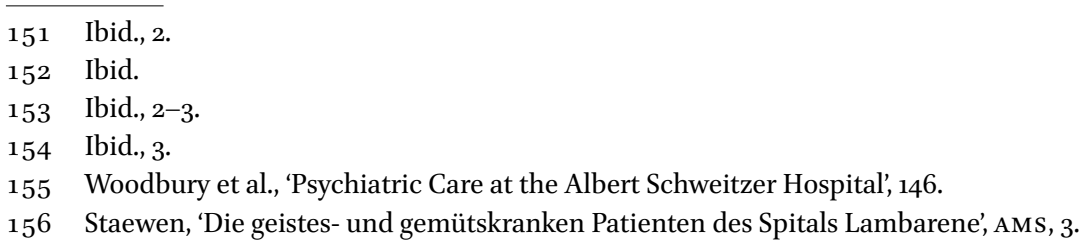


for the virtues of manual labor, but at the same time it also sought to prevent the individualization that was thought to accompany the imposition of European values and which was believed to be harmful to Africans' mental health.

The 'psychiatric family' at the Albert Schweitzer Hospital was not thought suitable for Europeans. They would disturb the dynamics and would not bear it. Schweitzer explained to his friend Arthur Stoll that European psychiatric patients were not to be attended to by Africans, 'because it would depress and agitate them.. ${ }^{157}$ In 1925, a French war veteran with 'nervous disorders' was brought to the hospital from a nearby lumber camp. Schweitzer believed that his condition was due to an old war wound that had been aggravated once again by sun stroke. Schweitzer demanded that the local colonial administrator pay for the patient's journey home to France, back to his own family so to speak, because 'he complicates my service a lot.' ${ }^{158}$ This repatriation did not occur, and the patient passed away shortly after Schweitzer had sent this request. Schweitzer's fixation with the dangers of sunlight is frequently referred to by visitors and staff. ${ }^{59}$ According to one anecdote, when Schweitzer did not feel well for a number of weeks in 1924, he explained his own condition with reference to holes in the ceiling through which the sun could penetrate. ${ }^{160}$

Another European psychiatric case that is described in detail in the sources is that of Roger Ghigo. After Ghigo was repatriated to France in 1948, Schweitzer related the patient's case history to his doctor in Marseille. Ghigo had come to the hospital with a 'strong mania', which included hallucinations as well as episodes of great agitation and sadness. Schweitzer ordered to keep him away from African staff and patients at the hospital, and to treat him with morphine and scopolamine. When his condition improved, Ghigo ate at the table for European staff in an attempt to provide him with a feeling of community. Once again, Schweitzer suspected that the sun might have had an influence in causing Ghigo's illness, since it shone directly onto the desk where he usually worked. In addition, as in a number of similar cases that he had experienced, Schweitzer believed that the malaria drug Atebrine might also have been to blame for Ghigo's condition. Schweitzer hoped that in Europe Ghigo's 'electroshock treatment will have good effects'.161

\footnotetext{
157 Schweitzer to Stoll, 29 June 1948, AMs.

$15^{8}$ Schweitzer to Garnier, 9 March 1925, AMs.

159 Siefert, Meine Arbeitsjahre in Lambarene 1933-1935, 138; Mai, Albert Schweitzer und seine Kranken, 10; Munz-Boddingius, 'Meine Chance und Freude, Hebamme in Lambarene gewesen zu sein'.

16o Schweitzer, 'Mitteilungen aus Lambarene. Erstes Heft, 1924', 61-62.

161 Schweitzer to Alliez, 27 November 1948, AMS.
} 
Schweitzer's belief in the superiority of European 'civilization' - or, at the very least, its uniqueness - is rendered obvious in these examples. However, in contrast to the diagnoses of doctors in other colonies when Europeans fell mentally ill, Schweitzer did not directly link mental disorders among Europeans to a longing for their own 'civilization'. Nevertheless therapy for European psychiatric patients was, as for Africans, partly intended to restore their sense of belonging. This objective was to be achieved by ultimately sending mentally ill Europeans back home, where they could also be treated with electroconvulsive therapy, a technology that had never been considered worthy of acquiring in Lambaréné.

\section{Accommodating the Mentally Ill at the Hospital: Perspectives on Safety}

During his first stay in Lambaréné, Schweitzer wrote of agitated psychiatric patients and that 'if I keep them at the station, they fill it with their screams.' ${ }^{162}$ When one such individual was brought to the hospital for treatment, Schweitzer resolved this issue by ordering the patient and his family to camp on a sandbank some distance away, where he paid them several visits per day. ${ }^{163}$ In 1924 , when the hospital's buildings were still made out of bamboo and brickwork from leaves, a sleeping sickness patient suddenly developed 'states of excitement' and became 'dangerous'. A more solid wooden cell was subsequently built to accommodate cases like him. ${ }^{164}$ It was still not possible, however, to house 'loud insane persons' for an extended period of time, even in this new cell, 'because the other patients can't bear it next to them.' ${ }^{165}$ Furthermore, the new structure had not been sufficiently secured. In March 1926, 'a madman $[\ldots]$ tears down the cell for the mentally ill and breaks out, spreading terror everywhere in the hospital.' ${ }^{166}$ In the following months, Schweitzer rejected a number of 'dangerous' mentally ill people. ${ }^{167}$ As he explained to Maud Royden, his contact person at the Guildhouse congregation, 'I don't have the desired number of solid wooden huts to lock them up safely'.168

\footnotetext{
162 Schweitzer, 'Notes et Nouvelles de la part du prof. Albert Schweitzer. Deuxième rapport', 18.

163 Ibid., 18-19.

164 Schweitzer, 'Mitteilungen aus Lambarene. Erstes Heft, 1924', 56.

165 Schweitzer, 'Mitteilungen aus Lambarene. Zweites Heft, 1924-1925', 157.

166 Schweitzer, Mitteilungen aus Lambarene. Drittes Heft, 1925-1927, 24.

167 Ibid., 24-25.

168 Schweitzer to Royden, Juillet 1926, AMs.
} 
At the hospital's new site, which opened in early 1927, psychiatric patients were housed in cells with wooden floors rather than the 'moist soil' used in its previous accommodation for the mentally ill. ${ }^{169}$ This unit, financed by donations from the Guildhouse, had to be vacated in January 1930 to make space for dysentery patients to be quarantined, ${ }^{170}$ but a fund from a deceased member of the Guildhouse congregation provided further money to construct a new building for psychiatric patients (see Illustration 43). It contained seven cells, which had all been constructed so as to ensure that the patients would be 'locked up, but it has air and light, like it's outside'. When this unit was opened in September 1930, representatives from the both missions and from neighboring villages attended the ceremony, suggesting that psychiatric care was regarded as an important issue by a wide range of actors in the area. ${ }^{171}$

Psychiatric patients, however, continued to present problems for the hospital personnel. The nurse Elsa Lauterburg-Bonjour voiced staff members' concerns about the security risks that they posed:

Since we do not have the necessary security measures, it is not uncommon for a lunatic to break out. Although they are imprisoned in thickwalled single cells during episodes of raving madness, if the seizure outbreaks unexpectedly, scary scenes can occur. ${ }^{172}$

A main challenge for the staff was to ensure peace and quiet for other patients. In late 1933, an additional building for mentally ill patients was constructed. Schweitzer justified this expense with reference not only to the need for more space to accommodate psychiatric patients, but also to the fact that 'we have so many noisy insane people, who cause sleepless days and nights to the others and upset them'. According to Schweitzer's proud report, the six new cells were 'even bigger and airier' than the ones in the building from 1930. ${ }^{173}$

In August 1934, the French doctor Roger le Forestier painted a radically different picture of the living conditions experienced by psychiatric patients at the hospital:

The nurses' good hearts are saddened when they look at our fools behind the wooden bars of the designated huts. They wonder if it is more

169 Schweitzer, Mitteilungen aus Lambarene. Drittes Heft, 1925-1927, 49.

170 Schweitzer to Rieder, 19 January 1930, AWHS. Emily Rieder, Noel Gillespie's mother, was also linked to the Guildhouse congregation.

171 Schweitzer to Royden, 30 September 1930, AMs.

172 Lauterburg-Bonjour, Lambarene: Erlebnisse einer Bernerin im afrikanischen Urwald, 16.

173 Schweitzer to Royden, 27 January 1933, AMs. 
humane to treat fools by caging them like wild animals, or to let them live and die freely in the forest? Perhaps we could find a way, for example by building an isolated acclimatization area like the hut of the dysenterics. ${ }^{174}$

To improve their situation, Le Forestier further proposed measures to occupy psychiatric patients in the wider hospital. These were, however, already partly in effect, as revealed in the examples of Mombo and others, and would be intensified over the course of the following three decades. Le Forestier had arrived in Lambaréné to serve at the hospital for the usual two-and-a-half-year term approximately six weeks before writing this letter, which was already the second that he had composed to Schweitzer with suggestions on what could be improved at the institution. ${ }^{175}$ This 'urge to continuous reforms and changes,',176 a characteristic to which Schweitzer and the personnel who were loyal to him did not take kindly, led to Le Forestier's departure only three months after his arrival.

Le Forestier believed, unlike Schweitzer, that 'our indigenous fools are very different from the European fools.' ${ }^{177}$ Le Forestier's rather progressive argument for the time that psychiatric patients in Lambaréné required more space did follow a racial logic. 'Keeping the natives, born for the wide open spaces, in a wooden cage, seems to me to be a psychological fault', he wrote. As proof of the ineffective or even harmful nature of the treatment for psychiatric patients at the hospital, Le Forestier added that 'by the way, one of them killed himself in his cage.' ${ }^{178}$ This incident was also described by his colleague Dr. Goldschmid:

One of our insane men (you didn't know him anymore, he was here since January 1934) hung himself in his cell a few days ago. He made a strong noose out of his loincloth and strangled himself in an almost kneeling position. Jean Mendoume and Miss Alice saw him at 10 o'clock in the morning and wanted to bathe him at 11 o'clock. In the meantime the thing happened. ${ }^{179}$

174 Le Forestier to Schweitzer, 23 August 1934, AMs.

175 The first letter consisted of eighteen pages. See: Le Forestier to Schweitzer, 5 August 1934, AMs.

176 These are the words of Dr. Goldschmid, who was very loyal towards Schweitzer. See: Goldschmid to Schweitzer, 22 August 1934, AMs. See also Schweitzer's letters to his secretary, Emmy Martin, from the same period.

177 Le Forestier to Schweitzer, 23 August 1934, AMs.

178 Ibid.

179 Goldschmid to Schweitzer, 31 July 1934, AMs. 


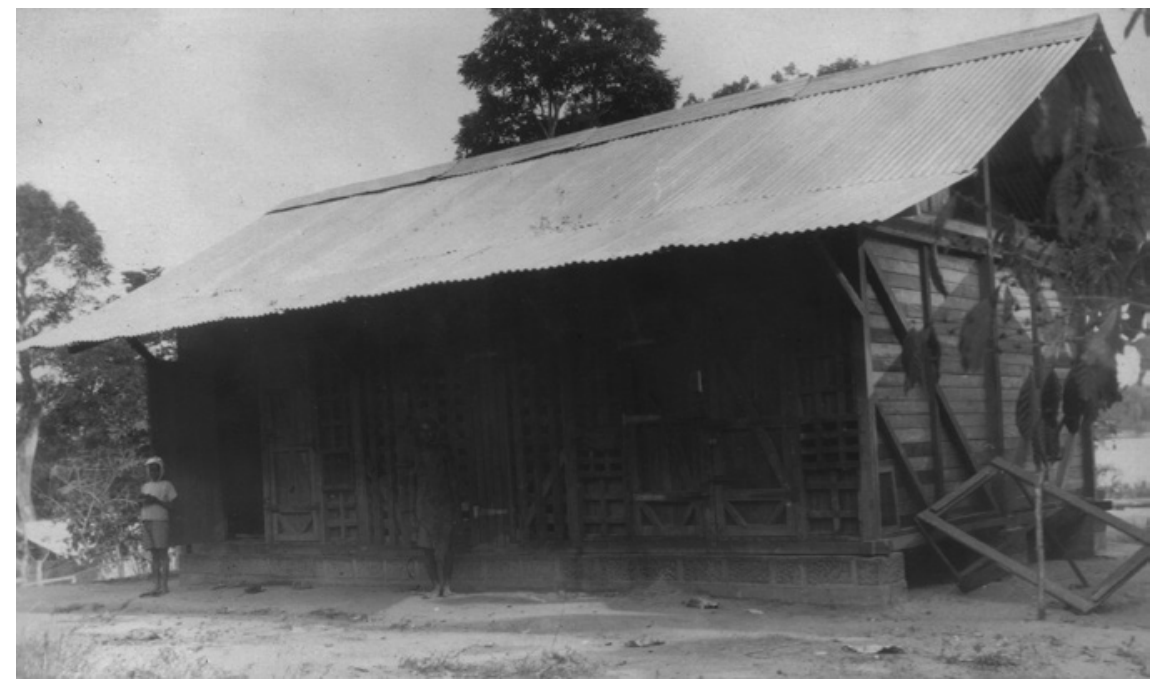

ILLUSTRATION 43 The psychiatric ward, 1931

(C) ARChives CENTRALES ALBERT SCHWEITZER GUNSBACH

Goldschmid did not comment further on this episode, which represented the most dramatic dent to the harmonious image normally invoked by the hospital staff to characterize the treatment of psychiatric patients. Not only did this suicide clearly demonstrate the limits of psychiatric therapy, it also showed that not even patient safety could be guaranteed at the hospital.

By the 196os, the psychiatric cells stood completely empty without even a bed, but were still arranged according to the mental state of their occupants, specifically their degree of agitation (see illustration 44). One building consisting of six rooms was reserved for the 'least disturbed individuals', while two other buildings, also with six cells each, were designed to ensure 'maximum security'. 180

Both the accommodation and the treatment of psychiatric patients were not devised primarily according to their needs, but with those of the hospital staff and other patients in mind. Breitenstein recalled that her twenty patients lived as an isolated group on the margins of the hospital grounds, where they 'disturbed the others as little as possible'.181 Dr. Friedman, who supervised Breitenstein, admitted that often the only option open to him and his fellow doctors when treating psychiatric patients was to administer 'tranquilizers so

180 Andrews, 'Psychiatric Facilities at the Albert Schweitzer Hospital', ${ }_{524}$

181 Breitenstein, 'Meine Arbeit mit den geistes- und gemütskranken Menschen in Lambarene', 71 . 


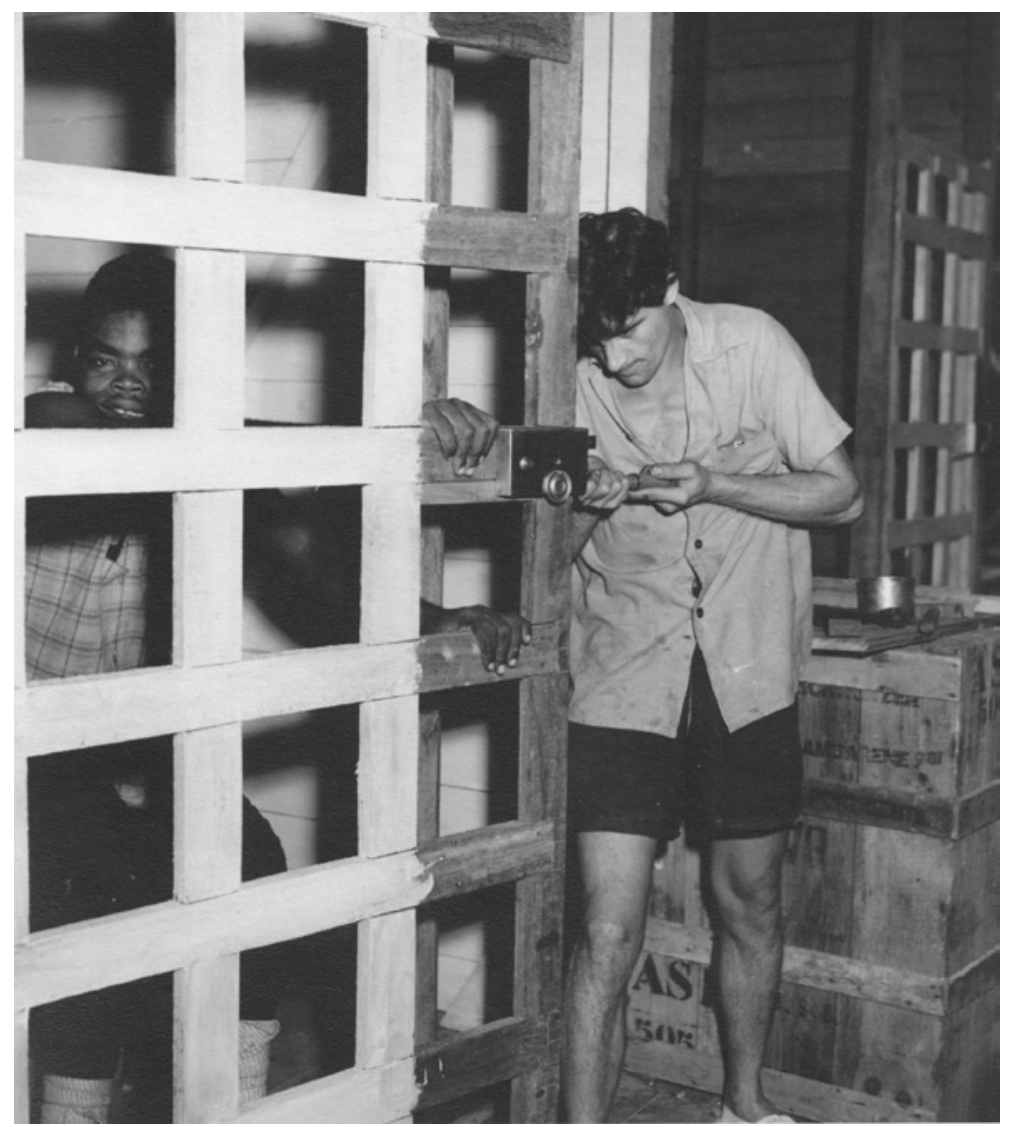

ILLUSTRATION 44 The carpenter Erwin Mathis renovating what might be a psychiatric cell, early $1950 \mathrm{os}$

(C) ARChives CENTRALES ALbERT SCHWEITZER GUNSBACH

that they would not become too dangerous.' ${ }^{182}$ Once again, Friedman displayed his therapeutic pessimism here, while also revealing staff members' anxieties about the potential for psychiatric patients to become violent.

A different set of safety concerns worried patients and their families, as three examples demonstrate. In 1961, Dr. Friedman informed visitor Götting about a man who felt haunted by spirits. As the Christian son of a catechist, the victim formed part of the modernized Gabonese middle class. When his father died, he was convinced that the protection that he believed his father had provided had vanished. Maintaining that spirits were now instructing him to unbury his family's 'fetish', he followed their orders, but 'he neglected [...] to

182 Günther and Götting, Was heisst Ehrfurcht vor dem Leben?, 169. 
worship' it. Subsequently, his business worsened. At the spirits' command, he then broke into his neighbor's house, where he destroyed the porcelain. This, he claimed, awoke his neighbor's spirits, which started to fight against his own. Finally, the neighbor woke up, subdued him and brought him to the hospital in ropes. 'Now he is here, and ponders how he could possibly win the terrible fight eventually', Götting concluded the story. ${ }^{183}$ For his part, Friedman again believed that this patient was beyond his medical competencies. This case suggests that Gabonese regarded spiritual and physical safety as interconnected and multidimensional concepts. While hospital staff organized psychiatric care and accommodation in a way that would protect themselves and other patients from the aggressions of the mentally ill, psychiatric patients felt that the hospital provided them with safety from the aggressions of malicious forces.

The second example on local safety concerns is the story of Eugène, a businessman who lived in Lambaréné, which was recounted by Staewen in 1964. Eugène and his wife had been unable to have children together. He had thus resolved to take another wife, a decision that so infuriated his first wife that she had threatened to poison him if he married a second time. Ignoring her warning, Eugène married a second wife, in response to which his first wife left him. Two years later, he began to believe that his family was plotting to kill him. His 'persecution mania' and 'agitation' subsequently intensified to such an extent that, after several months, he was brought to the hospital by these very relatives. There, according to Stawaen, Eugène was not cured - '(this persecutional disease is unfortunately often incurable)', the author explained - but he felt safe: "Nothing can happen to me here", he says, "I can feel safe in Doctor Schweitzer's hospital. Evil people can't achieve anything here". ${ }^{184}$ Eugène's story contains a number of familiar elements: the partly Europeanized protagonist, the involvement of his family, the fear of being poisoned. Eugène was in a state of constant fear, presumably of his family to poison him, which was why Staewen considered him sick. Significantly, this case provides us with a glimpse into patients' imaginations and motivations: from Eugène's perspective, he was not the cause of danger, but the one in danger.

It was not only patients with acute symptoms who appreciated the sense of safety that the hospital provided. Staewen cited the example of a recovering psychiatric patient whose father requested that she stay on at the hospital as an aide. He had brought her there after a 'wild bout of ravaging madness', which she had experienced a few months after getting married in Libreville.

183 Ibid., $172-73$.

184 Staewen, 'Die geistes- und gemütskranken Patienten des Spitals Lambarene', AMs, 1. 
Her father feared that she would experience a relapse if she returned there, a view with which she agreed. As she reportedly emphasized, 'I'd like to stay here very much. Here everyone is friendly to me, and they have said that I work well, ${ }^{185}$ thereby subscribing to Schweitzer's rhetoric of work as salvation. Moreover, she and her father both hoped that she would find a sufficient degree of shelter from the intimidations of modernity in Libreville, as well as protection from an intimidating individual, her husband. Still fearing herself to be in danger and her mental health under threat, she sought the continued protection of the Albert Schweitzer Hospital.

Schweitzer showed some awareness of psychiatric patients' conceptions of the hospital as a place of safety. He wrote that most patients considered the hospital, just like mission stations, as a place where 'taboos, curses, and magic were powerless'; they came not so much to benefit from medical care, but to be somewhere where 'the sinister powers, to which they feel exposed to, have no reach'. ${ }^{186}$ Augustin Emane's interviewees confirmed this interpretation. They regarded the Albert Schweitzer Hospital as a place of safety from 'all the schemings that are part of the world and cosmogony' and a site that was marked by the absence of any sort of conflict. ${ }^{187}$ Many Gabonese considered the area to be a zone of powerful spirits. The fact that Schweitzer maintained his hospital on these specific grounds, where the Galoa king Nkombe had resided, contributed to this perception and to the sense of permanence attributed to the work of both men. According to Emane, the hospital thus became a place where 'the encounter between the world of whites and that of the blacks' occurred 'without the usual conflicts'.188

Njambi, our introductory case, stayed at the hospital some three decades before most of the other patients referred to in this chapter (see Illustration 45). Concluding his story allows us to recap many of the chapter's key tropes. Njambi became a familiar member of the hospital community; indeed, he may well be the most talked about patient in the hospital's history. As the story goes, however, he was constantly afraid of being sent away. ${ }^{189}$ Although he was usually considered a 'quiet' patient who needed to be protected from his 'loud' counterparts, ${ }^{190}$ he was known to display (self-) destructive tendencies and to

\footnotetext{
185 Ibid., 2.

186 Schweitzer, Afrikanische Geschichten, 61.

187 Emane, Docteur Schweitzer: une icône africaine, 105-6.

188 Ibid., 109-12.

189 Schweitzer, Mitteilungen aus Lambarene. Drittes Heft, 1925-1927, 53; Lauterburg-Bonjour, Lambarene: Erlebnisse einer Bernerin im afrikanischen Urwald, 16.

190 Schweitzer, 'Briefe aus dem Lambarene Spital Pfingsten 1931', 8; Bähr, Albert Schweitzer: Leben, Werk und Denken, 129.
} 


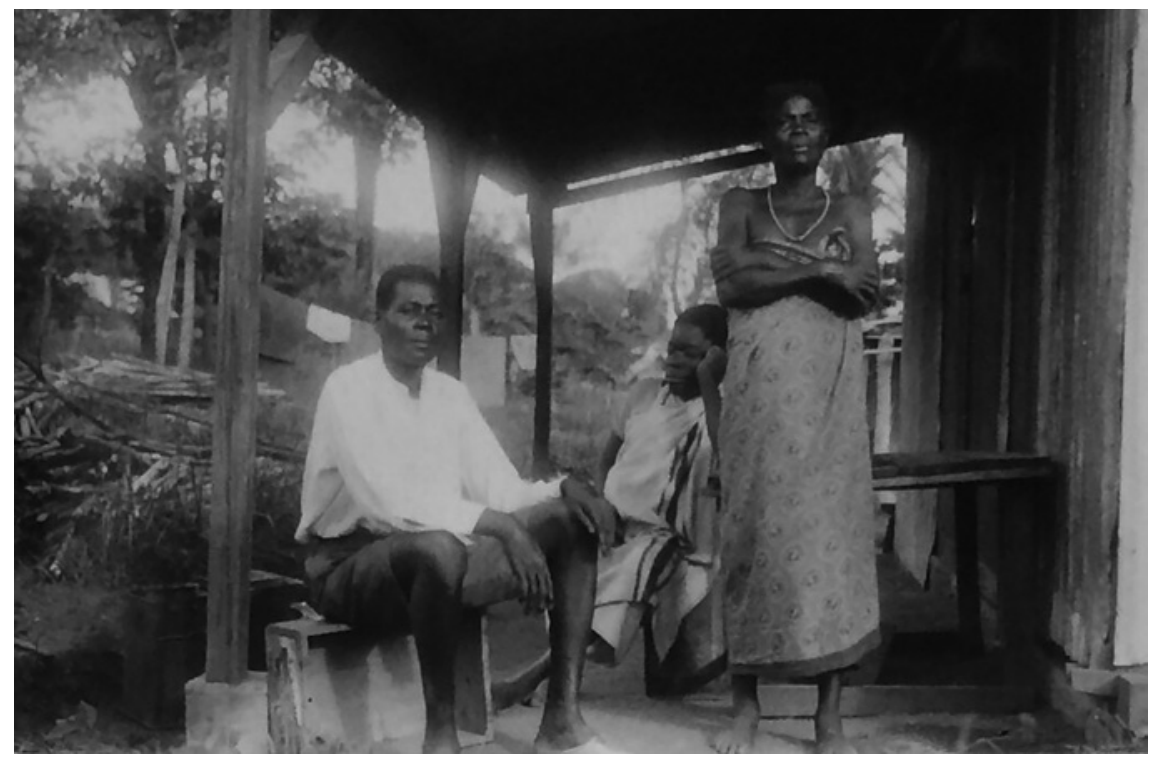

ILLUSTRATION 45 Njambi (front left), an unidentified nurse, and a sleeping sickness patient, early $1930 \mathrm{~s}$

(C) ARChives Centrales Albert SCHWEItZer GUNSBACH

experience 'loud' emotional outbursts. Elsa Lauterburg-Bonjour described one of those, which occurred in early 1931:

Last Sunday, while my husband was performing an emergency operation and the doctor was on a mission station, N'Jambi, a tall, strong lad who has been doing light work in the hospital for three years, suddenly suffered an outburst of rage. He had locked himself in his cell with petrol and matches and uttered loud threats. In order to prevent a hospital fire, my husband, who had been called here, tore open the locked door by force. At that moment bottles and open knives rushed towards him, but they missed their target. ${ }^{191}$

This account illustrates why hospital staff were so concerned about safety. Given all the dangerous objects that Njambi wielded in this anecdote, staff members appear to have exhibited an almost naïve trust in a man who had killed his wife, 'in the delirium' as Schweitzer, who had known him since 1913, insisted towards the Guildhouse congregation who symbolically adopted him

191 Lauterburg-Bonjour, Lambarene: Erlebnisse einer Bernerin im afrikanischen Urwald, 16. 
in $1930 .{ }^{192}$ Medical personnel were repeatedly required to subdue Njambi; in Lauterburg-Bonjour's account, for example, an unnamed auxiliary, probably Jean Mendoume, played a decisive role in restraining him. Drugs would then be used to calm him down further:

A brave helper courageously threw himself at the possessed man and after a hot struggle could take another knife from him, but carried a bad blow. Calmed by morphine, the lunatic soon sat in his cell, praised France and Napoleon and begged for chocolate. The next day he whimpered ashamed and contrite through the small air hole: 'Moi honte, moi beaucoup honte', and begged for the mercy of the Christian god. ${ }^{193}$

Following this episode, Njambi remained incarcerated in his cell for four months, after which he was allowed to go for short walks under the escort of two auxiliaries. ${ }^{194}$ Apart from Mendoume, drugs, and confinement, Schweitzer himself was key to pacifying Njambi. Indeed, Siefert identified Njambi as proof of Schweitzer's special knack with psychiatric patients. 'Dr Schweitzer often went to the insane, and you could observe how soothing he was to them, for example when he stood with the raving mad Tschambi and chatted with him', she wrote: 195

Njambi illustrates how much attention and value were given to the care of mentally ill people at the Albert Schweitzer Hospital. He was provided with escorts to enable him to leave his cell, even though this in turn allowed him to continue to threaten staff and patients and left them feeling unsafe. He shows how staff aimed to regulate the movements of their psychiatric patients, but was not able to fully control their moods. Schweitzer reported in 1933 how the personnel had learned to deal with Njambi's outbursts, a strategy in which Mendoume played an important role:

Yesterday evening, Tschambi [...], after having been well enough to move around in freedom for months, suddenly began to make confused and dangerous speeches again. Fortunately, his guard Mendume heard it and had the presence of mind to immediately clear his cell (in which he had piled up dangerous tools and empty bottles to be used as projectiles). So we could lock him up there without him being able to resist when he,

192 Schweitzer to Rieder, 5 April 1930, AwHs.

193 Lauterburg-Bonjour, Lambarene: Erlebnisse einer Bernerin im afrikanischen Urwald, 16.

194 Schweitzer to Schweitzer Comittee, 2 July 1931, AWHS.

195 Siefert, Meine Arbeitsjahre in Lambarene 1933-1935, 57. 
after his habit, entered it as soon as the evening bell rang. For this presence of mind Mendume received a fine gift. ${ }^{196}$

Given the menacing acts that Njambi committed, it is notable that Schweitzer chose to emphasize his supposedly dangerous monologues. Despite the threat that he posed, Njambi's freedom appears to have remained considerable; however, his outbursts did no longer come completely unexpectedly, with staff members, especially Mendoume, learning to anticipate their arrival.

On 24 September 1936, Dr. Goldschmid predicted that Njambi would die the following night of the 'galloping consumption' that he had acquired. 'The poor man was completely lucid in the last few days and not confused at all', Goldschmid explained. ${ }^{197}$ In the letter in which the doctor confirmed Njambi's passing, he remarked that 'for him it was a relief, we no longer have the heavy sorrow with him, yet we felt sorry for him.'198

\section{Conclusion}

Colonial doctors in general and psychiatrists who visited the Albert Schweitzer Hospital posited that the stresses of modernity triggered mental illness among Africans. The case histories that they presented in their texts, such as those of the businessmen Eugène and J.D., support this interpretation. Part of the reason why such patients were considered mentally ill was that they were judged to be 'insufficiently other.'199 This dimension is emphasized less in sources written by hospital insiders. In these documents, which discuss patients like Leo and Njambi, the authors focus on more universal human character flaws, such as a violent temperament or an extreme feeling of guilt. Patients displaying such traits 'surfaced up' 200 after committing a serious crime or when working for Europeans. In many of the cases described from the hospital, it were relationship problems that triggered psychiatric symptoms. In these instances, however, it was usually husbands who were treated at the hospital, while wives remained 'hidden patients. ${ }^{201}$

\footnotetext{
196 Schweitzer, 'Briefe aus dem Lambarene Spital Juli 1933', 8.

197 Goldschmid to Schweitzer, 24 September 1936, AMs.

198 Goldschmid to Schweitzer, 10 October 1936, AMs. In this letter, Goldschmid confirmed that Njambi had died on 26 September 1936.

199 Vaughan, Curing Their Ills, 101.

200 Jackson, Surfacing Up.

201 Studer, The Hidden Patients.
} 
The frequent reports of mentally ill individuals who were brought to the hospital in chains or ropes, as well as the relatively low number of psychiatric cases who were treated there, suggest that only mentally ill persons who exhibited certain symptoms ended up at the hospital. The numerous accounts of local healing methods not only indicate how these fascinated European observers, but also suggest that the number of mentally ill Gabonese must have been substantially larger than the total of patients who underwent hospital treatment. European observers, including staff from the hospital, perceived local treatment methods as violent, ostensibly so in order to overcome the malicious powers that were often considered by Gabonese to be the cause of mental illness. It was from such forces that patients, usually supported by their relatives, sought protection at the Albert Schweitzer Hospital. The institution thus acted as a relief station for communities unable to cope with particular manifestations of mental illness.

Visiting doctors offered a positive assessment of the hospital's combined treatment regime of drugs and occupational therapy, a strategy that aimed to cure psychiatric patients rather than simply confine them. While the hospital's approach to pharmaceutical treatment was consistent with that which it applied in relation to other diseases, its focus on putting patients to work conformed to Schweitzer's conception of the 'civilizing mission'. Labor was the feature of Western 'civilization' that Schweitzer believed was most worthy of being spread, a conviction by which he justified his interference in the everyday lives and values of his patients. In psychiatric care, this practice took on a therapeutic dimension as staff sought to recreate the sense of community that they believed the mentally ill had lost. In many ways, psychiatric care encapsulated the morals and practices championed at the Albert Schweitzer Hospital: treatment was improvised, but the days of patients, gardiens, staff, and visitors were highly structured, with labor their central feature. 